\title{
DUŠA, NJENE (STRAN)POTI, DRUŽBENO NADZORSTVO IN KAPITALIZEM ${ }^{1}$
}

\author{
Prof. dr. sc. Zoran Kanduč*
}

UDK: 130.121

Ur.: 11. rujna 2017.

Pr.: 4. listopada 2017.

Izvorni znanstveni rad

\section{Povzetek}

Tekst uvodoma osvetli razmerje med telesom in , dušo “, pravzaprav duševnimi pojavi, saj te metafizične entitete ni niti $v$ objektivnem niti $v$ subjektivnem svetu - za razliko od konkretnega, nenehno spreminjajočega se toka zavestnih izkušenj (ki so za posameznika nekaj najbolj realnega, čeprav še vedno ne vemo, kako nastanejo in čemu služijo) -, za nameček pa je tudi ni mogoče utemeljiti ali pojasniti z evolucijsko teorijo. Duša (v svoji enoviti in nesmrtni formi), ki jo Bog podari le človeški „kroni stvarstva“, obstaja samo v religiozni perspektivi in torej kot „,zgolj“ intersubjektivna, v kolektivni domišljiji in komunikaciji vzpostavljena in ohranjajoča se realnost, ki ima še vedno vse prej kot zanemarljiv vpliv na precejšnje število ljudi, in to ne le vernikov. Dognanja bioloških ved pa čedalje bolj rušijo tudi vero $v$ obstoj svobodne volje in enega samega, nedeljivega in avtentičnega (,resničnega") jaza (sebstva), ki je v optiki liberalnega humanizma ultimativni vir smisla, ekonomskih odločitev ter estetskih, moralnih in političnih sodb. Osrednji del sestavljajo analize dojemanj človeške duševnosti in njihov vpliv na organizacijo družbenega nadzorstva, izvršsevanje oblasti in upravičevanje hierarhij, ki so izvorno praviloma vselej namišljene, sčasoma pa postajajo vse bolj empirično otipljive in okostenele: kot zloslutne prerokbe, ki se uresničujejo same - dokler jih ,oni in one spodaj “ (dozdevno manjvredni in običajno zapostavljeni, zatirani, izkoriščani, prezirani ali celo osovraženi subjekti) s političnim bojem ne postavijo pod vprašaj, kar se $v$ zgodovini pripeti pomenljivo redko, zelo počasi in ne vedno uspešno. $V$ zvezi s tem je posebna pozornost namenjena razgrnitvi in preučitvi različnih pomenov čustveno močno otovorjene besede „svoboda“. V sklepnem delu steče beseda o duševni motenosti in normalnosti, in sicer predvsem $v$ povezavi $z$ nasilnim vedenjem in različnimi načini soočanja posameznikov $z$,, vse

* Dr. sc. Zoran Kanduč, izvanredni profesor na Institutu za kriminologiju pri Pravnom fakultetu u Ljubljani; zoran.kanduc@pf.uni-lj.si

1 Ovaj rad je sufinancirala Hrvatska zaklada za znanost projektom IP-11-2013-2287 „Legal Status and Real Position of People with Mental Difficulties - Interdisciplinary Approach and European Perspectives" i Sveučilište u Rijeci potporama znanstvenim istraživanjima 13.08.1.3.02 „Interdisciplinarni pristup u istraživanju statusa osoba s duševnim smetnjama kroz prizmu konvencijskog prava“. 
preveč človeškim " problemom raznovrstnega trpljenja kot (po vsej verjetnosti neodpravljive) tegobe, ki te ne doleti le zaradi te ali one smole, zle usode ali nesrečne konstelacije zvezd in planetov, ampak že zgolj zato, ker si živ, ker si kot subjekt ujet v življenje - v neuspeh lastnega nerojstva - in z njim spete naravne mehanizme, na katere pa se vse prepogosto prilepi še kup družbeno, kulturno in medosebno generiranega gorja. Najbolj na kratko in karikirano rečeno: človeška eksistenca = duševna motnja. Ta težava se dandanes vse bolj „, rešuje“ "s kupovanjem komercialnih dobrin in storitev, ki obljubljajo doživljanje prijetnih občutkov (in eo ipso srečnost), in z uživanjem zdravil ali (zakonitih in nezakonitih) drog, ki neposredno spreminjajo posameznikov biokemični sistem. To pa ima več kot otipljive kriminogene učinke, saj je večina kriminalnega vedenja posredno ali neposredno povezana s posameznikovo težnjo po sreči (s hrepenenjem po prijetnih občutkih in netoleranco do neprijetnih občutkov).

Ključne besede: duševnost, telo, nadzorstvo, oblast, hierarhije, svoboda, samokontrola, duševne motnje, nasilje.

„Človek, o katerem se nam govori in ki naj bi ga osvobodili, je že sam v sebi učinek podjarmljenosti, ki je še precej globlja od njega. $V$ njem biva 'duša' in ga nese $v$ življenje, a je le kolesce $v$ obvladovanju, ki ga oblast izvršuje na telesu. Duša, učinek in orodje politične anatomije, duša, ječa za telo. “

(Foucault 1984: 34)

„Ekonomija je metoda, toda cilj je, da spremenimo dušo. "

(Margaret Thatcher; navedba v Harvey

2012: 34)

\section{UVODNE OPAZKE O DUS̆I IN TELESU}

$\mathrm{Z}$ dušami so križi in težave, in to ne le s tako ali drugače motenimi, ampak tudi z bolj ali manj normalnimi. Zadrege so praktične in teoretične, ene in druge pa so tesno povezane, nemara že kar nerazvezljive. Toda pozor, kaj sploh je „duša“ (če predpostavimo, kar gotovo ni neproblematično, da je o njej mogoče govoriti v ednini)? To je vsekakor sila nenavadna entiteta, neoprijemljiva, izmuzljiva in vsaj na videz popolnoma drugačna od vsega drugega, kar utegnemo v življenju srečati na naši spolzki in vijugavi poti do smrti kot končne (in neredko že težko pričakovane) postaje. Zdi se, da se duševnost razlikuje tudi od živega telesa (kot pojavne oblike fizične razsežne snovi), njegovih celic (temeljnih gradnikov), tkiv in organov. Celo 
če si s pikolovsko pozornostjo ogledujemo človeške možgane, to najkompleksnejšo organsko tvorbo, ne bomo v njih opazili nobenega značilno psihičnega pojava, npr. občutka, misli, jaza, spomina ali domišljijske podobe. Je torej duša nekakšen „svet zase“ (mikrokozmos), posebna ali svojevrstna substanca, ki je strogo ločena od telesa in možganov? Če upoštevamo dognanja sodobnih znanstvenih raziskav, bo odgovor po vsej verjetnosti nikalen. Že lep čas ni namreč nobenega dvoma, do so duševne manifestacije in funkcije močno odvisne ne le od delovanja številnih specifičnih sistemov (predelov ali nevronskih vezij) v možganih, marveč tudi od telesa kot takega, ki jih po kemičnih in živčnih poteh neprestano zalaga $z$ informacijami o številnih aspektih življenjskega procesa. ${ }^{2} \breve{C}$, denimo, pride do te ali one možganske motnje (npr. zaradi poškodbe, bolezni, staranja in kemičnih ali farmakoloških sprememb), se to pogosto odrazi v predrugačenju duševnih stanj ali procesov. Še več, že dolgo ni več skrivnost, da je mogoče $\mathrm{z}$ neposredno stimulacijo specifičnih možganskih delov ustvariti občutja, zaznave, čustva in misli, ki ne ustrezajo dejanskemu stanju. Recimo: oseba, ki ji dražijo vizualni korteks, poroča, da nekaj vidi, čeprav so njene oči ves čas zaprte, ${ }^{3}$ ali pa električni tok, ki steče skozi njene možgane, povzroči, da iznenada in brez vsakega subjektivnega razloga občuti znatno žalost, začne jokati in nato še hlipati, njeno celotno obnašanje izžareva globoko bridkost, zavest ji preplavijo obupa polne, črne in samomorilske misli, ki ji življenje naslikajo kot popolnoma nesmiselno, ničevo in nagnusno. ${ }^{4}$ Na podlagi tovrstnih eksperimentov je torej mogoče sklepati, da so duh, ki vznikne iz biološkega tkiva (na način, ki zaenkrat resda še ni nedvoumno pojasnjen), možgani in telo pravzaprav nerazdružljive pojavne oblike enega in istega

2 Damasio (2008: 185) domneva, da so ključno stičišče med duševnimi podobami, ki se nanašajo bodisi na zunanjost (npr. vidne, slušne, tipne, vohalne in okušalne zaznave) bodisi na notranje okolje in organe (npr. občutenje bolečine ali ugodja), in dejavnostmi, ki potekajo v telesu, specifični možganski predeli, ki z nevronskimi vezji izdelujejo stalne in dinamične živčne vzorce, svojevrstne ,zemljevide“ stanj, procesov in modifikacij v organizmu. To implicira, da je npr. zaznavanje (duševna podoba ali „ideja“) realnosti, ki se nahaja zunaj organizma, pravzaprav stvaritev možganov, ne pa zgolj pasivna zrcalna slika tega ali onega predmeta ali dogodka. Fizična struktura neke zunanje entitete, npr. klavirskega koncerta, povzroči raznovrstne modifikacije ali „afekcije“ telesa (ki je z njo v interakciji), na podlagi katerih se v možganih ustvarijo vidni, slušni, gibalni in čustveni ,zemljevidi“ (živčni vzorci, izdelani v skladu z značilnostmi človeškega organizma), biološki temelji duševnih podob, ki jih izkusi poslušalec. Če drži, da je naša duševnost sestavljena iz idej, ki predstavljajo različne nevronske upodobitve (,kartografiranje“) telesa, ali to pomeni, da so možgani, v katerih ždimo od rojstva do smrti, sprva le prazen list, ki je pripravljen, da ga popišejo poznejši biološki signali? Damasio (2008: 195) poudarja, da so človeški možgani že ob rojstvu vse prej kot tabula rasa, saj so opremljeni s prirojenim znanjem o tem, kako naj upravljajo organizem (usmerjajo življenjske procese in se odzivajo na dogodke v zunanjem okolju), in z avtomatiziranimi spretnostmi, ki že vnaprej določajo številne ideje o telesu. Ko možgani ukažejo telesu, da preide v določeno stanje ali vedenje, hkrati ustvarijo tudi duševne podobe, ki temeljijo na tovrstnih modifikacijah organizma. Težnje in čustva so najbrž najboljši primer takšne ureditve: „Ko pride v telesu do pomanjkanja energije, možgani ta upad zaznajo in sprožijo stanje lakote - težnjo, ki bo privedla do popravkov neravnovesja. Ideja lakote vznikne iz upodobitev telesnih sprememb, ki jih ta težnja sproži.“”

3 Za podrobnejši prikaz tovrstnih eksperimentov glej Dolenc (2015: 39-43).

4 Za natančnejši opis in interpretacijo tega nenavadnega primera glej Damasio (2008: 65-72). 
organizma.

A duša je - navkljub vrtoglavemu kopičenju obetavnih znanstvenih spoznanj in teoretskih perspektiv, ${ }^{5}$ ki jo razlagajo, opisujejo in razčlenjujejo - še vedno precej skrivnostna, in to celo (paradoksno?) za tiste, ki so ji najbližje (ker je pač, kot smo se naučili reči, „njihova“). ${ }^{6}$ Kako naj si jo sploh predstavljamo? Opcij, ki so nam ponujene že z izročilom, zagotovo ni malo. Recimo: (a) duša kot domačija, temačna ali svetla, utesnjujoča ali prostrana, zračna ali zadušljiva notranjost, kjer prebiva jaz (ali subjekt), njen domnevni posestnik ali vsaj iluzorni gospodar; ${ }^{7}$ (b) duša kot bojišče, kjer se spopadajo dobre in slabe sile, npr. zavestne in nezavedne, kultivirane (in podružbljene) in živalske (zverske?), civilizirane in barbarske, moralne in nemoralne, družbeno sprejemljive (ali celo normativno pričakovane) in nedopustne, egoistične in altruistične, konstruktivne in destruktivne (Eros in Thanatos); (c) duša kot gledališki oder, na katerem $\mathrm{v}$ glavnih in stranskih vlogah nastopajo poleg nepogrešljivega posameznikovega ,jaza“ (kot sive eminence?) še domišljijsko predelani najpomembnejši liki v njegovem življenju, še zlasti tisti iz najbolj rosnega, otroškega obdobja, večinoma preživetega v družinskem krogu; (č) duša kot kinodvorana, v kateri se pred enim samim samcatim gledalcem, ki pa prevzema različne ideale („oči“ v drugem, v katerih je videti vreden ljubezni) in spreminjajoče se identitete, vrtijo kajpak z občasnimi, počitku namenjenimi presledki - novi in stari, dokumentarni in fiktivni filmi (npr. dolgočasni in zanimivi, veseli in žalostni, komični in tragični); (d) duša kot ,troedina“ muzejska zgradba z eksponati evolucije človeške vrste, ki izvirajo

5 Znanstveni modeli duševnosti (ki so kajpak vse prej kakor fotografske slike realnih objektov) odgovarjajo na naslednja tipična vprašanja. Kako je duševna „snov“ organizirana ali regulirana? Iz česa je duša sestavljena? Kako se duševni pojavi razvijajo v času? Kako psihične vsebine vstopajo in izstopajo iz ,notranjega sveta“? Kako so duševni dogodki (procesi in stanja) povzročeni? Katere so in kako se oblikujejo poglavitne osebnostne ali značajske kategorije, v katere je mogoče razvrstiti človeška bitja?

6 Ta problem je - davno pred psihoanalizo in evolucijsko psihologijo - mučil že svetega Avguština (2003: 204), ki je sodil, da je „duh pretesen, da bi zaobjel samega sebe“.

7 Freudova teza, da ,jaz“ ni gospodar niti v svoji lastni hiši (saj se mora zadovoljiti zgolj z neredko precej izmaličenimi - drobci informacij o tem, kaj se dogaja v „njegovih“ nezavednih plasteh duševnosti), je dandanes že splošno znana, tako rekoč lieu commun. Wright (2008: 312-313) pa opozarja, da je v luči evolucijske psihologije videti človeška duševnost še dosti bolj nepresojna, in sicer predvsem zaradi mnogoterih, raznolikih in globoko zakoreninjenih virov samoprevare in nejasne ali zabrisane ločnice med zavestnim in nezavednim: „Darvinizem gre celo tako daleč, da se skoraj vpraša o smislu pojma resnice. Družbene razprave, ki naj bi vodile do resnice - moralne, politične in včasih celo akademske - so v darvinističnem pogledu le goli preizkusi moči." No, če imajo naše duše toliko skrivnih in mrakobnih kotičkov in če je v medčloveških odnosih toliko manipulacij ali (samo)prevar, potem se vsiljuje zoprno vprašanje, zakaj ali čemu bi karkoli ali kogarkoli sploh še jemali resno. Radostna vest? Hm, odvisno. Vsekakor pa se zgledno rima z značilno postmodernim cinizmom, ki, najbolj milo rečeno, ne zaupa več nobenemu etičnemu idealu ali politični viziji „boljše“ (npr. bolj pravične, solidarne in racionalne) družbe, saj sprejema (neredko z večjim ali manjšim odmerkom ironije) le še zasebne, individualizirane utopije. Iz tovrstne („odčarane“) kulturne „drže“ pa se zlahka izcimi še nekaj neprimerno bolj zloveščega, namreč nihilizem, žalostno razvrednotenje najvišjih vrednot in ciljev (prepričljivih odgovorov na ključno vprašanje, čemu živeti in trpeti), implozija smisla in vsakovrstne „bolezni duha“ (Galimberti 2010: 19-20), npr. trpka usahnitev upanja, mučno dolgočasje in turobna depresija. 
iz najstarejšega plazilskega jedra (sedeža najosnovnejših nagonov), prasesalskih in novosesalskih možganov (ki omogočajo abstraktno mišljenje, govor in zatorej tudi racionalizacijo in upravičevanje bolj primitivnih vzgibov in ravnanj); (e) duša kot prizorišče nepomirljivih in dinamičnih konfliktov, na katerem jaz bolj ali manj nepretrgoma (in pogosto tesnobno) išče vsaj zasilne kompromise ali ravnovesja med načelom ugodja in načelom realnosti (ali med pritiski „onega“ in zahtevami „nadjaza“), skrbi za lastno varnost pred nesprejemljivimi, bolečimi ali neprijetnimi psihičnimi vsebinami (npr. z nizom obrambnih mehanizmov, kot so potlačitev, zanikanje, razcepitev, projekcija, sublimacija, reaktivna formacija, izolacija, fragmentacija in identifikacija z agresorjem), išče smisel tostranske (absurdne?), skoraj praviloma vse prej kot brezskrbne, zadovoljive ali srečne eksistence ali pa si prizadeva - če mu po napornih delovnih (izobraževalnih, službenih, potrošniških in družinskih) obveznostih sploh še preostane zadosti časa in energije - doseči „samouresničitev“ (karkoli že to pomeni). In tako naprej.

Dokaj razširjena je predstava, da je duševnost ekskluzivna sfera zasebnih, pravzaprav najintimnejših izkušenj, ki jih zares pozna - vsaj kolikor so zavestne - le jaz, ki jih doživlja, (ob)čuti, izkuša ali zaznava. A tudi za subjekt, ki ponosno zaseda dozdevno najbolj privilegirano gledišče, so (,njegovi“) duševni pojavi neredko izvor zamotanih ugank. Če pojmujemo dušo kot notranji prostor, kje se potem nahaja meja, ki jo ločuje od vseh drugih, človeških in nečloveških bitij, in iz česa je narejena ta lupina, v kateri živi subjekt kot neke vrste homo clausus, ${ }^{8}$ jetnik ali zaprti človeček? Kako introspektivno spoznavamo (ali prepoznamo) svoja psihična stanja, procese, dejanja in dogodke, ne da bi že poprej vedeli, kaj je to, kar hočemo opazovati? Ali spoznanje predrugači (ali celo izmaliči) psihične pojave ali pa jih pušča popolnoma nespremenjene? Kako naj vem, da je želja X, ki jo nedvomno občutim kot svojo,

8 Elias (2000: 46-58) ocenjuje, da je subjektivna predstava (ali občutek) „sebstva v lupini“ (nekakšnega samozadostnega, neodvisnega in samobitnega ,jaza“, ki je zaklenjen v svoji „,notranjosti“ - npr. v slogu Leibnizove „monade brez oken“, Descartesove „misleče substance“ ali Kantovega kritičnega spoznavnega subjekta, ki nikakor ne more prodreti do „stvari na sebi“ - in ki je ločen od soljudi in drugih stvari, ki so „zunaj“ njega) v sodobnih evropskih družbah izredno razširjena, trdovratna in sprejeta kot nekaj najbolj samoumevnega. Po njegovem mnenju je tovrstno doživljanje samega sebe odraz povečanja posameznikove zmožnosti, da se v mišljenju distancira od samega sebe (in kajpak od vseh drugih predmetov opazovanja ali spoznavanja), predvsem pa je posledica visoke stopnje družbeno razvitega in individualno pridobljenega - zavestnega in samodejnega (in torej nezavednega) - nadzora nad čustvi in nagoni. Z drugimi besedami, to, kar ,jaz“ intimno občuti kot „zid“ (ali „kletko“), ki ločuje njegovo „notranjost“ od družbene in naravne ,zunanjosti““, je pravzaprav rezultat okrepljene samoprisile (npr. v obliki „racionalnega razmišljanja“ in „,moralne vesti“), tj. izrazitejšega trdnejšega, razsežnejšega, enakomernejšega in bolj ali manj neprekinjenega - zadrževanja ali brzdanja nagonskih in emocionalnih vzgibov, ki jim je na ta način onemogočen ali vsaj močno omejen neposreden (brez dovoljenja višjih psihičnih nadzornih instanc) dostop do motoričnih mehanizmov (skeletnih mišic, telesnih gibov in delovanja). Elias zato poudarja, da je subjektivna izkušnja „v duševni notranjosti zaprtega jaza“, neustrezna in zavajajoča (pri tem pa se sklicuje tudi na slovito Goethejevo misel, da nima narava ne jedra ne lupine, zato ni v njej nikakršnega znotraj ali zunaj). Predlaga, da jo nadomestimo z idejo o človeku kot „odprti osebnosti“, ki ima $\mathrm{v}$ družbenih razmerjih večjo ali manjšo stopnjo relativne avtonomnosti, hkrati pa je od rojstva do smrti usmerjen k drugim ljudem, od katerih je navsezadnje tudi odvisen. 
zares moja, in sicer v tem smislu, da ni določena od zunaj in je torej po svoji naravi pravzaprav „heteronomna“, izvirajoča iz (pogosto že scela pozabljenih) srečanj z drugimi osebami, predmeti ali dogodki, ki so tako ali drugače aficirali moj organizem ${ }^{9}$ (telo, možgane in dušo)? Če si prizadevam izraziti svoj resnični ali pristni jaz (npr. onkraj „fasade“ družbenih vlog, ki jih igram v vsakdanjem življenju), kje in kako naj ga najdem (če kaj takega sploh obstaja)? Če sem bolj skromen in hočem zgolj avtonomno določiti lastne potrebe, se vsiljuje vprašanje, katere naj vzamem za svoje, ${ }^{10}$ v kolikšni meri in kako naj jih zadovoljujem. Če občutim neko čustvo (npr. ljubezen, naklonjenost ali spoštovanje), ki ga gojim do osebe Y, kako naj se prepričam, da je zares pravo, ne pa zgolj privid, s katerim slepim samega sebe (če predpostavim, da je samoprevara sploh mogoča) in posredno seveda še njo? In tako dalje.

\section{DOJEMANJA (IN ,KONSTRUKTI“) DUŠE, DRUŽBENO NADZORSTVO, OBLAST IN HIERARHIJE}

Težave se zaostrijo, ko skušamo ugotoviti, kaj ždi ali se plete v dušah drugih človeških bitij (,,ali X govori resnico ali se mi laže?“”, „me želi Y pretentati ali pa mu vendarle kaže zaupati?“, „,me je Z res vesel, ko se srečava, ali pa se, hinavec, samo pretvarja?“, ,,ali so laskave pohvale, ki mi jih izreka Ž, iskrene, ali pa so mi namenjene zgolj zaradi obeta te ali one usluge, ki jo pričakuje od mene?"). A to še ni vse. Še huje je, če moramo dognati ali rekonstruirati stanje duha neke osebe v preteklosti. To je problem, s katerim so pogosto soočeni agenti kazenskopravnega sistema, v zadnji

9 Na to zagato je opozoril že Spinoza (1988: 260), in sicer z uvidom, da se posameznik običajno zaveda le svojih dejanj in gonov (želja, teženj, hotenj ali razlogov za delovanje), ne pa tudi vzrokov, ki določajo to, za kar se žene. Za natančnejšo analizo heteronomne narave človeških želja glej Lordon (2010: 30-35).

10 Kako opredeliti, kaj dejansko potrebujemo za - po možnosti kajpak dobro - življenje? Na kratko: težko, če že ne scela nemogoče. Za ,zdravje“ strukturno iracionalnega in destruktivnega kapitalističnega gospodarstva je namreč bistveno, da so ljudje razlaščeni ne le produkcijskih sredstev (ter nadzora nad delovnim procesom in njegovimi rezultati), marveč tudi izkušnje zadostne, omejene ali končne zadovoljitve potreb (glej Fischbach 2012: 292-299). Človeške potrebe morajo rasti, saj brez stanovitne nezadovoljenosti (ali nezadovoljstva) ne bi bilo mogoče brezmejno in neskončno oplajanje (akumulacija) kapitala. Kronična „anomija“ (Durkheim 2006: 207-215) je conditio sine qua non za reprodukcijo gospodarstva, katerega edini smoter je produkcija presežne vrednosti, npr. s podaljševanjem delovnega časa, intenziviranjem dela ali povečevanjem produktivnosti (s kooperacijo, delitvijo dela in uporabo strojev). Za ohranitev in krepitev tega zgodovinsko specifičnega sistema razrednega gospostva in izkoriščanja je zatorej nujna ne le reprodukcija posameznikov kot kapitalistov (ki jih motivira lov za čim večjim profitom) in mezdnih delavcev (ki morajo za preživetje prodajati svojo delovno silo, saj potrebujejo - v položaju absolutne materialne heteronomije - denar za nakup življenjskih potrebščin), marveč tudi kot stalno nepotešenih potrošnikov. V produkciji načrpana presežna vrednost se mora namreč realizirati v obliki denarja (ki je izhodišče in cilj poslovanja zasebnega tržnega podjetja). Zato je treba „oplojeno“ blago prodati zainteresiranim in plačilno sposobnim kupcem, ki se prostovoljno - brez fizične prisile ali grožnje in v slogu dozdevno „suverenega“ subjekta (,kralja“), obdarjenega s famozno freedom of choice - podrejajo diktaturi ponudbe. Za podrobnejše analize potrošniške željnosti glej Lebowitz (2014: 4-9); Heinrich (2013: 121135); Hamilton (2007: 69-86); Kurz (2000: 123-133). 
instanci sodniki. Je ravnal X naklepno ali malomarno? V kakšnem razmerju sta bila njegova vednost in hotenje (namere ali želje) do prepovedane posledice? Se je zavedal, kaj počne in da je njegovo (aktivno ali pasivno) ravnanje objektivno nedopustno? Je imel svoje delovanje (telesne gibe) pod nadzorom? V nezavidljivem položaju, v katerem se znajde oseba, ki ji državni organ očita storitev kaznivega dejanja in nad katero mrko čemi grožnja negativne sankcije, je dokaj naivno od nje pričakovati iskrenost, odkritost ali resnicoljubnost. Storilec se običajno skuša izmakniti odkritju, pregonu, obtožbi, obsodbi in sankciji (še posebej, če je kazen zares vredna svojega zloslutnega poimenovanja). Če zbrani dokazi prepričljivo pokažejo, da je „onkraj razumnega dvoma“" prav on povzročitelj protipravne škode, mu preostane le še to, da si prizadeva odpraviti ali zmanjšati svojo odgovornost s sklicevanjem na opravičljivo psihično stanje (in se tako izmakniti kazenski sankciji ali jo vsaj omiliti). ${ }^{11} \mathrm{~V}$ ta namen se lahko opre na lastno iznajdljivost ali na nasvete pretkanega advokata, ki je za stranko (in mimogrede še za svojo denarnico) pripravljen, kot je mogoče vse pogosteje slišati, „narediti prav vse“ (neredko tudi tisto, kar ni prav). Opcije, ki jih ima obramba na voljo, se kajpak razlikujejo od primera do primera. A navadno najbolj vžge, če se ji posreči, da prikaže storilca kot žrtev vzročnih sil, za katere ne more odgovarjati in ki so ga posamič ali družno naredile takšnega, kakršen pač je (bog pomagaj), vključno z dejanjem, ki je de iure določeno kot kaznivo. Obramba lahko (z)mehča ali razblini storilčevo odgovornost s psihološkimi, sociološkimi ali biološkimi argumenti (s katerimi sicer bolj ali manj vešče in $\mathrm{z}$ večjim ali manjšim uspehom žonglirajo tudi kriminološke teorije o družbenih in individualnih vzrokih kriminalnega vedenja). Zgolj za grobo ilustracijo: duševnost obtožene osebe (npr.

11 Pašukanis (2014: 146) opozarja, da je odgovornost v arhaičnem kazanskem pravu temeljila predvsem na škodi: naklepno, malomarno ali naključno dejanje so presojali glede na negativne posledice, ki jih je povzročilo. Odgovornost ni bila zgolj individualna, marveč tudi kolektivna. Recimo: otrok je nosil krivdo za grehe staršev, rod je odgovarjal za zločine svojih članov, gospodar je bil deležen povračilne kazni zaradi škode, ki jo je (ne)posredno naredila njegova domača žival. Če je plemič ubil hčer, ki je (kot lastnina) pripadala drugemu pripadniku aristokracije, je bil morilec po Hamurabijevem zakonu kaznovan tako, da so usmrtili njegovo (nedolžno) hčerko (za komentar mezopotamskega pojmovanja pravičnosti glej Harari 2015: 113-116). Sodobno kazensko pravo temelji - v skladu z doslednim individualizmom meščanske kulture - na strogo osebni odgovornosti, ki ne vključuje le dejanja in škode, marveč tudi diferencirane oblike krivde (psihološke prvine). Pašukanis (2014: 148) poudarja, da se na pojem krivde, ki sicer ni znanstven, lepijo številne zagate, zlasti v zvezi s predpostavljeno svobodo volje. Srčiko njegovega argumenta je mogoče povzeti takole: Vzroki, ki vplivajo na dejanja psihično nenormalnega (in zatorej neprištevnega) posameznika - npr. dednost (geni) in zunanje okolje (življenjske razmere) -, določajo tudi vedenje popolnoma normalnega (in zatorej odgovornega) storilca. V luči spleta okoliščin, ki so povzročile ta ali oni dogodek (slabo ali dobro posledico), ni nobene podlage za to, da bi eni verigi sklepanja dali prednost pred drugo. Ruski filozof ob tem dodaja, da kazen, ki se uporablja kot pedagoški ukrep (namreč neodvisno od pravne ideje ekvivalenta), sploh ne predpostavlja in ne potrebuje predstave o prištevnosti in svobodni izbiri. Njena racionalnost temelji zgolj na sposobnosti zavedanja povezave med posameznikovim dejanjem in škodljivimi ali neprijetnimi posledicami, ki jih povzroči, in na njegovi zmožnosti, da si zapomni njen obstoj: „V tem smislu med prištevne, dovzetne za vplivanje $\mathrm{v}$ določeni smeri, spadajo tudi nekatere osebe, ki po kazenskem zakoniku niso odgovorne za svoja dejanja, tj. otroci od najzgodnejše starosti naprej in psihično nenormalne osebe.“ 
njeno zavedanje in hotenje) naj bi bila pred (pre)močnim vplivom dejavnikov, kot so: (a) alkohol, droga ali zdravilo; (b) neubranljivi impulz, afekt ali kompulzija; (c) psihiatrično priznana in prepoznana bolezen ali motnja; (̌̌) sindrom pretepene žen(sk) e; (d) predmenstrualne težave; (e) zasvojenost z dejavnostmi, ki so zaradi svoje nevarne ali tvegane narave prijetno vznemirljive (ker so vir endorfinov, ki preplavijo kriminalčevo kri in ga navdajo s dobrim počutjem); (f) visoka stopnja testosterona; (g) pretirano prehranjevanje s slaščicami; (i) ekonomske težave (npr. brezposelnost, revščina, relativno prikrajšanje ali zadolženost); (j) nizka stopnja serotonina; (k) slabi (realni ali fiktivni) vedenjski zgledi (npr. na televizijskem ali računalniškem ekranu, na filmskem platnu, v družini, soseski, vrstniški skupini ali delovni organizaciji); (1) statusna deprivacija (glede na dominantne kulturne kriterije, po katerih se ocenjuje socialna vrednost ljudi in določa, v kolikšni meri so deležni pozitivne pozornosti, spoštovanja, ugleda, priznanja, naklonjenosti, občudovanja in zatorej neredko tudi zavisti); (m) bolj ali manj sistematična diskriminacija (zaradi pripadnosti manjšinski etnični ali verski skupnosti, barve kože ali spolne usmerjenosti); (n) pomanjkljiva zmožnost obvladovanja čustvenih in nagonskih vzgibov (npr. napadalnosti ali spolnega poželenja), ki je posledica neprimerne moralne vzgoje in pomanjkljivih ali neprimernih starševskih nadzorstvenih praks; (o) negativne reperkusije zanemarjanja ali (fizičnih, seksualnih in psihičnih) zlorab v otroštvu ali adolescenci; (p) socialna bolečina, ki je posledica neuspešnih medčloveških odnosov, ${ }^{12}$ zavračanja, izolacije, osamljenosti ali izključevanja. In tako naprej.

Čedalje boljši uvidi v delovanje človeških možganov, podkleteni s sodobno tehnologijo (npr. s tehnikami preslikavanja, ki omogočajo neškodljivo spremljanje njihovega delovanja $\mathrm{v}$ realnem času), so obdarili obrambo z vrsto novih opcij za spodbijanje ali zmanjšanje storilčeve kazenske odgovornosti. Njihova rdeča nit je zlahka opazna: dokazati je treba povezavo med storilčevimi možganskimi (strukturnimi in funkcionalnimi) anomalijami - npr. tumorjem (ki pritiska na amigdalo, središče za upravljanje čustev, zlasti strahu in napadalnosti), cisto ali poškodbami v prednjem režnju (predčelno skorjo, ki nadzoruje moralne občutke, nagonske in emocionalne reakcije in vedenje) - in to ali ono osebnostno, duševno ali vedenjsko motnjo, npr. nezmožnostjo učinkovitega obvladovanja agresivnosti, socio- ali psihopatskimi značilnostmi, pedofilsko spolno usmerjenostjo ... To je vsaj zaenkrat še precej težavna naloga, zakaj najprej je treba identificirati obstoj organskih nepravilnosti

12 Bauer (2008: 28-57) na podlagi najnovejših nevrobioloških dognanj poudarja, da je naravni cilj človeške motivacije (nagonskih agregatov življenjske volje ali „sistemov nagrajevanja“) doseči pozitivni socialni odziv in uspešne (kooperativne) odnose z drugimi. Še drugače rečeno, vse, za kar si prizadevamo v vsakdanjem življenju (npr. v izobraževanju, poklicnem delu, nakupovalnih in potrošniških aktivnostih, upravljanju finančnih sredstev in prostem času), ima z vidika naših možganov globlji in navadno nezavedni „smisel“ $\mathrm{v}$ tem, da meri na socialno priznanje ter vzpostavljanje, oblikovanje in ohranjanje dobrih odnosov z drugimi (še posebej s tistimi, ki jih štejemo za najpomembnejše). Bauer ocenjuje, da je tovrstna (prirojena) težnja pomembnejša celo od nagona po samoohranitvi. Če pa je to temeljno prizadevanje frustrirano, blokirano ali nerazvito (npr. zaradi slabih navezovalnih izkušenj v otroštvu in mladosti), je rezultat, socialna bolečina“, ki je posameznik ne doživlja le psihično, marveč tudi nevrobiološko, in ki ima za posledico bodisi žalost (in depresijo) bodisi agresivno vedenje (v skladu z reklom, if you can't join them, beat them"). 
(s tehniko možganskega preslikavanja), nato pa opredeliti njihov vpliv na določeno nevrobiološko (pre)dispozicijo in pojasniti, kako je patološki dejavnik X (bodisi sam ali v povezavi z drugimi motnjami) povzročil konkretno storilčevo dejanje. Zato ni presenetljivo, da sodišča (zlasti v ZDA, ki na tem področju orjejo ledino) največkrat upoštevajo nevrobiološke argumente obrambe ,zgolj“ kot olajševalno okoliščino pri odmeri kazenske sankcije. ${ }^{13}$ Po drugi strani pa velja upoštevati, da so - in zagotovo še bodo (po vsej verjetnosti že v bližnji prihodnosti) - spoznanja o delovanju človeških možganov (in njihovem določanju duševnih vsebin ali funkcij) koristna tudi za represivne in druge nadzorstvene aparate (javne in zasebne). V mislih imamo predvsem prizadevanja znanstvenikov, da spoznajo to, kar se dogaja $\mathrm{v}$ posameznikovi duševnosti, neposredno ali brez varljivih ovinkov, namreč neodvisno od njegovih subjektivnih in bolj ali manj izkrivljenih poročil (ki temeljijo na introspekciji), že zgolj z opazovanjem ali merjenjem nevrobiološke „podlage“ (možganskih „prstnih odtisov“) misli, spominov, čustev, zaznav ali teženj. ${ }^{14}$ Človeško bitje bi tako postalo za zunanje nadzornike (formalne in neformalne) popolnoma transparentno. Nič v njem ne bi več ostalo skrito. Izjemno izpopolnjeni bralniki (npr. funkcionalne magnetnoresonančne tomografije) bi v človeških možganih zanesljivo prepoznali laž, prevaro, sovražne misli, jezo ali agresivne vzgibe. Vizija (fantazma?) brezhibne, brezšivne, totalitarne družbene kontrole? Najbrž. Ne smemo pa prezreti, da je prav takšna nadzorstvena strategija imanentna tudi kapitalistični ekonomiji kot taki, ki si prizadeva - kolikor seveda ne trči ob učinkovit odpor ali upor - preliti celotno človeško življenje v kalup blagovne produkcije (v ,delovnem“ času) in blagovne potrošnje (v ,prostem“ času). ${ }^{15}$

Razkrivanje nevronskih, biokemičnih in genskih „upravljavcev duha“ je - ob tradicionalni spremljavi kulturoloških, socioloških in psiholoških teorij o vzrokih človeškega vedenja - zopet prignalo na plan zdaj že dodobra postarano vprašanje, ali je človeška volja (̌̌e) svobodna ali pa se je (že) treba sprijazniti z njeno determinirano naravo. Problem ni le teoretski, saj se nanj lepijo baje neznansko pomembne praktične - moralne, pravne, politične in verske - implikacije in reperkusije. ${ }^{16}$ Mnogi zato še

13 Hafner (2015: 90-94), ki je podrobno preučil vlogo in učinke nevrobioloških argumentov v kazenskem postopku, opozarja na odločitev vrhovnega sodišča ZDA, ki je v zadevi Roper v. Simmons prepovedalo izvrševanje smrtne kazni zoper obsojence, ki so storili kaznivo dejanje, ko so bili mlajši od osemnajst let. Ta razsodba se je opirala na znanstvene raziskave, ki so pokazale, da se prednji možganski predeli razvijejo pri človeškem bitju najkasneje (šele v prvi polovici dvajsetih let).

14 Za natančnejši prikaz in komentar tovrstnih nadzorstvenih tehnik v sedanjosti in prihodnosti glej Hafner (2105: 94-100); Harari (2015: 411-415); Dolenc (2015: 37-38).

15 Za izčrpnejšo analizo specifično kapitalističnega totalitarizma glej Kurz (2000: 111-112).

16 Radikalni predstavniki „nevrofilozofske“ kritike lingvističnega modela duše (tj. nazora, ki predpostavlja, da potekajo osrednji psihični procesi, vključno z nezavednimi, v formi govorice in so podrejeni njenim zakonitostim, npr. metafori in metonimiji) predlagajo, da bi se bilo treba - glede na to, da so možgani edina materialna podlaga naših kognitivnih procesov dokončno posloviti od vseh temeljih pojmov tradicionalne in ljudske (,spontane“) psihologije. $\mathrm{Da}$, odreči bi se morali pojasnjevalnim kategorijam, kot so namen, želja, mnenje, prepričanje in volja, na katere se ne opira zgolj posameznikovo vsakdanje, bolj ali manj samoumevno dojemanje samega sebe (z introspekcijo) in drugih človeških bitij (s pripisovanjem), marveč tudi veljavni kazenskopravni diskurz. Zakaj? Ker so ti koncepti, vsaj v luči tako imenovanega eliminativnega materializma, znanstveno neustrezna razlaga dejanskih procesov, ki potekajo 
vedno trdno verjamejo, da mora svobodna volja ohraniti status svetinje, ki jo je treba (za)varovati za vsako ceno. Če je avtonomna izbira med dobrim in zlim zgolj privid, subjektivna iluzija (čeravno evolucijsko koristna), ali je potem sploh še smiselno, da kogarkoli grajamo in hvalimo, kaznujemo (glede na krivdo in povzročeno škodo) in nagrajujemo (glede na zaslugo in prispevek k družbeni blaginji)? Če smo, kot se vse bolj dozdeva, samo bolj ali manj (ne)posrečeni rezultati interakcij med geni in okoljem (ali družbeno usmerjani biološki ,stroji“, bolj ali manj uspešno delujoči produkti kulturnega razvoja in brezciljne evolucije), potem tistih, ki delajo nedopustno škodo, ne kaže več obsojati (saj niso prav nič krivi), marveč jih velja (po)zdraviti (tako ali drugače reprogramirati) ali, če to ni mogoče, začasno ali trajno izločiti iz družbene arene. Stvari so videti očitno dovolj resne, da si zaslužijo vsaj miniaturni komentar. Najprej velja upoštevati, da ima ideja svobodne volje (liberum arbitrium) religiozno poreklo (v filozofijo jo je uvozil šele sveti Avguštin). Njena privlačnost je v tem, da ponuja možno rešitev za trd oreh vsake monoteistične vere. Namreč: kako pojasniti obstoj neznansko obsežnega in raznovrstnega zla, trpljenja in slabih stvari, ki so jih na tem svetu deležni celo dobri ljudje (ali vsaj dosledni verniki), če pa je stvarstvo izdelek (in objekt upravljanja) vsevednega, vsemogočnega in, dvakrat podčrtajmo, vsesplošno dobrega Boga? Za dualistično religijo (npr. zaratustrstvo, gnosticizem in manihejstvo), ki implicira ostro ločitev med slabim telesom (ali snovjo) in dobro dušo (ali duhom), to ni problem, saj pojmuje zlo kot samostojno ustvarjeno, samosvojo in neodvisno silo, nenehno bojujočo se proti Bogu, ki je v tej perspektivi predstavljen kot nesporno dober, ne pa tudi vsemogočen (ravno zato potrebuje izdatno angažiranost vernikov, ki mu morajo pomagati v njegovih nenehnih spopadih z neuničljivim sovražnikom). Monoteizem se skuša izvleči iz zagate tako, da prikaže obstoj zla kot posledico izbire svobodne volje, s katero je Stvarnik obdaril človeka, hkrati pa si je pridržal močan (skrajno zastrašujoč) adut, namreč večno trpljenje v peklu kot kazen za grešnike, ki so (lahkomiselno ali v želji po minljivih užitkih) popustili skušnjavam ali zapeljevanju Hudiča (ali Satana). ${ }^{17}$ Povejmo to še z drugimi, krepkejšimi besedami: Bog je ustvaril človeka kot bitje, ki ga ne določa noben arhetip, nobena omejitev, noben vnaprejšnji načrt (cilj ali smoter). In prav zaradi te temeljne, izhodiščne nedoločenosti (odsotnosti sleherne a priori začrtane življenjske poti) lahko človek zdrsi navzdol (do živalskih

$\mathrm{v}$ človeških možganih, in ker so rezultat sistematično privzgojene (ali priučene) zmote, ne pa kantovskega transcendentalnega videza, namreč neodpravljivih iluzij, ki so inherentne popolnoma pravilnemu delovanju uma. Za kritiko tovrstnih zamisli glej Bunta (2015: 17-24).

$17 \mathrm{Z}$ vpeljavo hudiča, ki zapeljuje $\mathrm{v}$ skušnjavo in (z)vabi $\mathrm{v}$ greh, in pekla kot najstrašnejše zamisljive kazenske sankcije, ki predpostavlja vero v življenje duše tudi po smrti telesa, se $\mathrm{v}$ monoteizem vtihotapi, tako rekoč skozi stranska vrata, dihotomija, ki sicer označuje dualistično religijo. A to ni nekaj, čemur bi se kazalo čuditi. Harari (2015: 226-228) opozarja, da vera v enega samega Boga praviloma ni teološko koherentna in konsistentna doktrina, marveč je po svoji naravi sinkretizem, namreč kalejdoskopska lepljenka monoteističnih, dualističnih, politeističnih in animističnih duhovnih zapuščin. Po njegovem mnenju je mogoče soobstoj reda (zakonov, ki vladajo stvarstvu) in neznanskega zla, ki trdoživo kljubuje dobremu, najbolj elegantno rešiti s predstavo o Bogu kot vsemogočnem stvarniku, ki pa je (žal) hudoben: „Toda za tako prepričanje ni imel dovolj poguma še nihče v zgodovini.“ Za podroben prikaz vsakovrstnega trpljenja, bolečin, nadlog in bede, ki se - od zunaj in od znotraj - nepopustljivo lepijo na človeško eksistenco, glej Hume (2000: 72-114). 
ali zverskih nižavij), zaide vstran ali pa se zmagoslavno povzpne do višjih, nemara celo božanskih bivanjskih oblik. ${ }^{18}$

V starogrški kulturi svoboda (eleuthería) ni bila atribut volje (ali duše), marveč državljanstva. Bila je torej politična (in ne psihološka) kategorija: svoboden je bil človek (po pravilu moškega spola), ki ni bil suženj (ki mu torej ni bilo treba delati za drugega, gospodarja, in ki se mu ni bilo treba pečati z ekonomsko dejavnostmi, nujno potrebnimi za vsakdanje zadovoljevanje življenjskih potreb). ${ }^{19}$ Svobodna je bila tudi polis, ki jo je upravljala skupnost državljanov (politično enakih, čeravno različnih glede na bogastvo ali posest in plemenitost rodu) in ki ni dolgovala tributov nobeni nadrejeni državi. Takšno pojmovanje se je ohranilo tudi v starem Rimu, dokler latinska beseda libertas ni doživela dramatične preobrazbe (pravzaprav pravniške redefinicije), tako da je skoraj ni bilo več mogoče razlikovati od zasebne oblasti gospodarja (dominium), ki ima pravico, da s svojo lastnino (ki vključuje tudi sužnje, dolžniške hlapce in odvisne kmete) počne karkoli (kar se mu zahoče), razen seveda tistega, kar je izrecno prepovedano z veljavnimi predpisi. Graeber (2014: 299-305) opozarja, da je to specifično koncepcijo svobode, ki je kratko malo izenačena z bolj ali manj absolutno oblastjo, podedoval tudi srednji vek, in sicer kot fevdalčevo pravico, da počne na ozemlju, ki je pod njegovim političnim ( $\mathrm{z}$ vojaško silo podkletenim) gospostvom, kar hoče (vključno z izkoriščanjem podrejenih tlačanov ali prisvajanjem presežkov njihovega dela). Tudi $\mathrm{v}$ kontekstu novoveškega kapitalizma je svoboda nerazvezljivo povezana $\mathrm{z}$ lastništvom. Moderno (meščansko) pravo priznava in varuje vse državljane kot formalne enake (podvržene istim veljavnim pravilom) in svobodne lastnike kot subjekte, ki prostovoljno - namreč brez fizične prisile, grožnje ali prevare - razpolagajo z vsem tistim, kar je (glede na biološko, družbeno in ekonomsko „loterijo“) pač njihovo, npr. z materialnimi dobrinami, nematerialnimi pravicami, telesom, denarjem, zemljo (naravnimi viri) ali delovno silo (prirojenimi in pridobljenimi telesnimi in psihičnimi zmožnostmi ali veščinami). To pa implicira, da meščanska pravna (razredno nevtralna) država že zgolj s striktnim varovanjem zasebne lastnine (ki predpostavlja dolžnost vseh državljanov, da se vzajemno priznavajo kot

18 Za klasično formulacijo predstave o človeku kot vnaprej nedoločenemu in zatorej svobodnemu bitju, ki lahko postane (iz svoje središčne pozicije v svetu), kar hoče (ali si zaželi), glej Mirandola (1997: 5-7). Ta ideja je še posebej navduševala renesančne in humanistične mislece in elite (glej Bauman 2016: 24-26), in to v obdobju, ko so trume pohlepnih in brezobzirnih španskih kristjanov v Ameriko prinašale civilizacijo smrti, zasužnjevanja, plenjenja, uničevanja in podjarmljenja (glej Berardi 2013: 196-197; Galimberi 2011: 381-386; Todorov 2014: 157178). Za analizo sodobnih - bioloških, antropoloških in filozofskih - pojmovanj nedefinirane, nespecializirane ali vsaj zelo pomanjkljivo določene „narave“ (kot nespremenljive ali metazgodovinske stalnice) človeške živali (ki je opremljena s slabotnimi instinkti, konstitutivno dezorientirana, vselej prezgodaj rojena, oropana vnaprejšnjega življenjskega vodila, obsojena na „večno otroštvo“ in odvisna od kulturnih „bergel“), glej Virno (87-111).

19 Za natančnejšo osvetlitev pojmovanja svobode $\mathrm{v}$ starogrški politični teoriji in praksi glej Arendt (2006: 153-162). Wood (2016: 40-49) pa poudarja, da je najpomembnejši rezultat antične demokracije pravzaprav kmečki državljan, namreč svobodni (avtonomni in bolj ali manj samozadostni) proizvajalec, ki ni več podrejen (kot podložnik ali hlapec) centralni državi ali aristokratski gospodi (zemljiškim lastnikom), tj. nadrejenim oblastnikom, ki si prilaščajo presežke njegovega dela. 
imetniki lastninske pravice) zagotavlja normativno podlago kapitalističnih razmerij gospostva in izkoriščanja. Človek, ki je razlaščen produkcijskih sredstev, ne pa tudi (nenehno porajajočih se) življenjskih potreb, in ki v blagovni ekonomiji potrebuje za svoje preživetje denar, mora namreč prostovoljno prodajati svojo (v organizmu zapakirano) delovno silo in si $\mathrm{v}$ ta namen sam poiskati gospodarja, ki ga bo oblastno podredil in izkoriščal (v zameno za mezdo). ${ }^{20}$

No, izenačenje svobode in gospostva ima tudi daljnosežne psihološke reperkusije. Vključuje namreč predstavo o človeku, ki je zmožen gospodovati samemu sebi, in to predvsem tako, da njegov duh, obdarjen s svobodno ali nedoločeno voljo (katere bistvena dejavnost vključuje ukazovanje in uboganje), obvladuje telo (kot neke vrste ločeno entiteto). A kaj če to ne drži? Iz zadrege, ki je plod novih in novih znanstvenih dognanj, se je mogoče izkobacati na več načinov. Naj izpostavimo vsaj nekatere najbolj pogoste. Bržčas najpreprostejša rešitev je v tem, da zarišemo ostro, neprepustno ločnico med teoretsko ali znanstveno vednostjo in praktičnim ali normativnim (moralnim in pravnim) diskurzom. Še drugače rečeno: v normativni perspektivi je (pred)postavka „nihil ex nihilo, nihil sine causa“" postavljena v oklepaj, suspendirana. Postulat naravne vzročnosti (ki se nanaša na svet fenomenov, v katerem se „svobodni jaz“ - tudi če morda dejansko obstaja - nikoli zares ne prikaže) pa ni odrinjen vstran zato, ker bi bil neuporaben za spoznavanje človeškega vedenja, npr. zaradi njegove nepredvidljivosti ali naše nezmožnosti, da bi spoznali prav vse vzroke, ki ga določajo. Poglavitni razlog je $\mathrm{v}$ tem, da normativne sodbe nujno predpostavljajo (avtonomnega) subjekta, ki je vzrok - poglavitno ali, še bolje, celo edino določilo - samega sebe (causa sui). To pa pomeni, da se od posameznika pričakuje, naj obravnava sebe in druge, kot da bi bilo človeško bitje svobodno, tj. nedoločeno $\mathrm{z}$ dednostjo, vzgojo, družbenim okoljem, kulturnimi vrednotami, empiričnim značajem in drugimi priložnostnimi vzroki. ${ }^{21}$

20 Za podrobnejšo analizo meščanske pravne države kot politične hrbtenice kapitalističnega izkoriščanja, zatiranja in izsiljevanja strukturno podrejenih prodajalcev delovne sile (ali, nemara še natančneje, samih sebe) glej Heinrich (2013: 224-228); Pašukanis (2014: 103116); Lebowitz (2014: 5-15). Graeber (2013: 59-60) ocenjuje, da je mezdno delo - ekonomska nujna dejavnost, ki ji večina ljudi še vedno žrtvuje večino budnega časa in življenjske energije - zgolj novejša oblika suženjstva: „Namesto da nas drugi prodajajo ali nas dajejo v najem, dajemo v najem sami sebe. V bistvu pa je to ista vrsta dogovora.“

21 Glej Jager (2006: 143-153). Za prikaz in komentar Kantove koncepcije „svobode kot dolžnosti“ (,,bodi svoboden!“) in praktičnega uma, katerega središče je svobodna volja (ki se kot skrivnostna „stvar na sebi“ izmika našim čutom, vključno z „,notranjim“, s katerim dojemamo sami sebe), glej Karatani (2010: 139-152). Pojmovanje, ki obravnava posameznika kot svobodno (in umno) bitje in ki torej ne postavlja pod vprašaj njegove (moralne in pravne) odgovornosti za lastna dejanja (storitve in opustitve), se zgledno rima tudi z našim prirojenim občutkom za pravičnost, ki uravnava vzajemni altruizem po načelu quid pro quo: dobro naj se povrne z dobrim (korenčkom), slabo pa s slabim. Skratka: ljudje, ki drugim povzročijo nedopustno škodo (krivico), si zaslužijo povračilno trpljenje (palico). Hegel (2013: 101) poudarja, da ima subjekt celo pravico do tega, da je za svoj zločin kaznovan, saj je na ta način „počaščen kot umno bitje“ (in ni obravnavan zgolj kot nekakšna „škodljiva žival“). Po drugi strani pa je treba upoštevati, da je mogoče kaznovanje in nagrajevanje človeških bitij upravičiti tudi v perspektivi doslednega determinizma, ki izhaja iz podmene, da je vsakdo produkt (ali, če hočete, ,žrtev") genov in okolja, tj. družbeno in kulturno programirani aparat, ki ga resda obhaja varljiv občutek svobode, a le zato, ker nima celovitega uvida v vse notranje in zunanje 
Takšno pojmovanje je še vedno precej razširjeno in navsezadnje tudi priljubljeno. Svoboda je namreč nadvse cenjena „dobrina“, pravzaprav vrednota par excellence. Le kdo ne bi hotel biti ali, če je podjarmljen in zatiran, postati svoboden? To, da se zavestno in voljno odrečeš svoji svobodi (in prostodušno prevzameš vlogo in status sužnja), ni le znamenje težko umljivega čudaštva, marveč kratko malo neizbrisne sramote. $\mathrm{Ne}$ pozabimo, da so ljudje pripravljeni za svobodo (in v njenem imenu) ubijati in umirati. Tudi zato je liberalizem ideologija, ki posamezniku hitro in neopazno zleze pod kožo, in sicer navadno celo tako globoko, da v njej ne opazi nič ideološkega, saj se mu zdi, da je zgolj verodostojen, samoumeven opis dejanskega stanja stvari (,tako pač je in pika"). Liberalizem dojema svobodo predvsem kot atribut razmišljanja in delovanja. Šteje se, da je posameznik svoboden, če lahko neovirano (ne da bi ga kdo izrecno priganjal, prisiljeval ali vlekel za nos) izraža ali udejanja svojo edinstveno osebnost (avtentično psihološko naravo) in sledi svojim lastnim interesom, nagnjenjem, preferencam, željam, mnenjem in prepričanjem. ${ }^{22}$ Zato ni presenetljivo, da se v takem kulturnem ozračju izrazito, pravzaprav pretirano (in navsezadnje tudi zmotno) poudarja vzročna vloga posameznika (zlasti njegovih osebnostnih značilnosti), ko je treba pojasniti to, kar počne, in to, kar se mu dogaja (podkrepitve), podcenjuje ali zanemarja pa se vpliv vlog, ki jih opravlja, pravil, ki jih mora upoštevati, pritiskov, ki jim je podvržen, in okoliščin, v katerih se nahaja. Posameznik je tisti, ki naj velja za ključnega avtorja svojih storitev in opustitev (za scenarista, režiserja, kostumografa, scenografa in glavnega igralca v lastnem avtobiografskem filmu). In le on sam je zatorej odgovoren (zaslužen ali kriv) za svojo srečnost in nesrečnost, dobro ali slabo

dejavnike, ki ga (v zadnji instanci biološko) določajo (v luči evolucijske psihologije so nekateri nagibi skriti „načrtno“, da bi zavestni akter - prav zaradi njihovega nepoznavanja - deloval bolj prepričljivo). V tem primeru se sankcioniranje pač opre na klasične utilitaristične argumente: kaznujemo zato, ker (in kolikor) menimo, da je ta nadzorstvena praksa družbeno koristna. Kazen je torej sprejemljiva, če zastrašuje ali odvrača potencialne in dejanske storilce, ,poboljšuje“ obsojence (npr. s prevzgojo, resocializacijo, izobraževanjem, terapijo in vcepljanjem delovnih navad), izloči (trajno ali začasno) nevarnega zločinca, preprečuje demoralizacijo lojalnih državljanov in tako dalje (glej Wright 2008: 331-340).

22 Če drži, da ljudje neznansko cenijo svojo svobodo (in kajpak zavidljiv privilegij, da živijo in delajo $\mathrm{v}$ free society), potem bi utemeljeno pričakovali, da bodo skrajno alergični na vse dejstvene in normativne ovire, ki se jim postavljajo po robu in tako ali drugače omejujejo njihovo življenje, in da bo vse, kar ogrozi ali omeji njihovo najljubšo vrednoto, v njih izzvalo neprijetno napetost, jezo, sovražnost, agresivnost, predvsem pa uporniško težnjo, da se čim prej vzpostavi stanje, v katerem bodo lahko počeli to, kar hočejo, in se jim ne bo treba ubadati z rečmi, ki jih dolgočasijo, odbijajo, onesrečujejo ali odtujujejo od njihovih najglobljih aspiracij. A to se zgodi nenavadno in pomenljivo redko. Beauvois (2000: 9-15) ugotavlja, da smo običajno priče ravno nasprotnim reakcijam. Ljudje namreč minimizirajo, zanikajo, ignorirajo, nevtralizirajo ali racionalizirajo vsakovrstne (celo očitno ponižujoče) omejitve, ovire in (implicitne ali eksplicitne) pritiske, ki so jih deležni. To pa velja še toliko bolj tedaj, ko se posameznik kot podrejeni vključi v oblastno strukturo (npr. v delovno organizacijo) na podlagi „svobodne izbire“ (čeravno podkletene z ekonomsko nujnostjo, željo po denarju, ki ga potrebuje za „golo“ ali vsaj za silo spodobno preživetje). V tem primeru je še bolj verjetno, da bo v tem, kar mora storiti ali opustiti (da bi prejel nagrado in se izognil kazni, s katero mu grozi izvajalec oblasti), videl nekaj, kar je zanj koristno (npr. za „samouresničevanje“ ali „osebnostno rast") ali privlačno (npr. kot poklicni „,izziv“). Le zakaj bi se sicer prostovoljno odločil za opcijo, ki je zanj zgolj negativna? 
zdravje, (ne)zaposljivost ali (ne)zaposlenost, bogastvo ali revščino, mladosten ali starikav videz, privlačnost in neprivlačnost, uspehe in brodolome v intimnih odnosih, srečnost ali nesrečnost. Njegove življenjske zmage zrcalijo njegove osebnostne poteze (npr. podjetnost, pogum, iniciativnost, ustvarjalnost, inteligenco, izobraženost, delavnost, preudarnost, daljnovidnost, vztrajnost in tako dalje) in so potemtakem scela zaslužene nagrade. Tako kot so njegovi porazi trpek odsev njegovih individualnih slabosti in pomanjkljivosti. V liberalni perspektivi poglavitna grožnja posameznikovi sakrosanktni svobodi niso le nasilna in premoženjska kazniva dejanja (kot kršitve lastninske pravice), marveč tudi država, še posebej tista (socialistična in potemtakem „totalitarna“ ali „zločinska“), ki si prizadeva skrbeti za „skupno dobro“, omejevati (npr. v imenu pravičnosti, solidarnosti ali človekovih pravic) izkoriščanje, zatiranje, ekonomske, socialne, politične in druge neenakosti ter se zoperstaviti „kreativni destrukciji“ kapitalistične ekonomije (njenim uničujočim učinkom na družbo, kulturo, naravno okolje in človeška bitja). Zasebne oblastne organizacije (podjetja, ki se ženejo za dobičkom) niso problematične, saj posameznik vanje vstopi pogodbeno in torej prostovoljno. V podreditev privatnem gospodarju privoli, ker sodi, da je to zanj iz tega ali onega razloga dobro (,tako je moja izbira in to preprosto dejstvo morate spoštovati, vsaka nadaljnja debata o tem ni le nesmiselna, ampak morda že žaljiva“"). ${ }^{23}$

Zdi se, da je nadvse cenjeno idejo svobodne volje mogoče uskladiti celo z znanstvenimi dognanji, ki namigujejo (ali nemara že dokazujejo), da je spontani občutek zavestnega jaza, da je prav on edini in suvereni avtor svojih odločitev in izbir (med različnimi opcijami, ki jih ima na razpolago v danih okoliščinah), pravzaprav zgolj prevara, potegavščina njegovih možganov. Ti naj bi se namreč dejansko „odločili““ že približno pol sekunde pred tem, ko se tega naposled zave še ,,svobodni““ subjekt. A pokazalo se je tudi to, da možganska (nezavedna) „odločitev“ vendarle ni dokončna: mogoče jo je preklicati, preprečiti njeno udejanjenje. ${ }^{24}$ In šele v tej točki ima ,jaz“ možnost izbire, ki je videti „,Svobodna“. X (npr. v obliki nagonskega ali čustvenega vzgiba), ki se pojavi v njegovi zavesti, lahko ,jaz“ upošteva ali zavrne. V tej perspektivi „Svoboda“ ni več pojmovana kot zmožnost, da posameznik samovoljno naredi to, kar se mu zahoče (kar si želi ali kar mu narekujejo osebna nagnjenja in interesi), ker mu ne stoji nasproti nobena zunanja, naravna ali družbena prepreka. Ta pojem je zdaj opredeljen tako, da se nanaša na zmožnost zavestnega nadzorovanja spontano

23 Spomniti velja, da se liberalizem (v stari in novi različici) ne predstavlja kot dominantna ideologija kapitalističnega sistema (kolikor jo ne nadomesti fašizem, ki je njegov zgodovinski sopotnik v boju proti socializmu), marveč kot znanost, celo kot ,nauk o vsem človeškem delovanju kot takem“ in zatorej tudi kot edino možno utelešenje neomadeževane racionalnosti. A liberalni teoretiki se ne zadovoljijo samo s spoznavanjem resnice o ljudeh in nadčloveškem (družbenoekonomskem) redu, ki se poraja iz tržnih transakcij in katerega zakonitosti so za laične smrtnike večinoma nerazumljive (zato je treba na vsak način omejiti njihov politični vpliv in zavarovati gospodarstvo pred nespametnim vmešavanjem „volilnih skrinjic“ in politično nadvlado). Iz vseobsegajoče „ekonomske znanosti“ izpeljejo politični program, objektivno zavezujoče norme in vrednote, ki naj uravnavajo vsa področja družbenega in kulturnega življenja. Upiranje tovrstni politiki bi bilo popolnoma nerazumno, celo znamenje „duševne bolezni““ (von Mises) ali na prvinskih čustvih utemeljenega ,atavizma“ (Hayek). Za podrobnejšo analizo in kritiko liberalizma glej Mastnak (29-43); Supiot (2013: 21-28).

24 Za celovitejši prikaz znanstvenih raziskav človeške svobodne volje glej Dolenc (2015: 39-43). 
porajajočih se vzgibov, misli in želja, pri čemer posamezniku ni v pomoč samo njegov razum (ali vsaj zdrava pamet), marveč tudi duševna zmožnost „potovanja v času“, namreč spominjanja in podoživljanja preteklih izkušenj in (pretežno domišljijskega) zamišljanja možnih prihodnosti (ali vživljanja v alternativne scenarije, ki zaenkrat še niso realizirani). Z drugimi besedami, svoboda je v tem, da narediš nekaj, česar nočeš, da si zmožen preprečiti impulzivno ravnanje, da si ti tisti, ki odloči, kateri psihični vzrok te bo določil, in da za to svojo izbiro prevzameš odgovornost. ${ }^{25}$ No, to, da je samokontrola nujni pogoj za posameznikovo prilagojeno življenje v skupnosti, je znano že od pamtiveka. Tega se še predobro zavedajo tudi vzgojitelji, ki morajo „malega divjaka“ (novinca, ki kot „tujec“ vstopi v dano družbeno in kulturno okolje) zdresirati, spraviti v red in k pameti, mu predočiti, kaj je prav in kaj je narobe, kaj je lepo in kaj je grdo, kaj se dela in česa se ne dela, kaj mora početi in česa se je treba vzdržati, kaj je možno in kaj je nemožno, kaj je normalno in kaj je nenormalno, kaj je okusno in kaj je gnusno, kaj je zdravo in kaj je bolno, kaj je čisto in kaj je umazano in tako dalje. Hkrati pa ga skušajo pripraviti do tega, da bo upošteval pravila družbenih (in družinskih) ,iger“, in sicer tudi ali predvsem tedaj, ko bo pregovorna mačka zdoma in ko se bodo miši zatorej znašle v skušnjavi, da bi zaplesale po svoje. To, kar bi utegnilo biti pri direndaju, ki spremlja delovanje agentov neformalne in formalne (pro- in reaktivne) družbene kontrole, vendarle nekoliko nenavadno, je izenačenje samokontrole s svobodo ,kot tako““. ${ }^{26}$ A ne glede na morebitne pomisleke (ali cinično muzanje) ni sporno, da mora posameznik za svoje uspešno brzdanje spontanih čustev in nagonov plačati zelo visoko in neredko tudi previsoko subjektivno ceno. ${ }^{27}$ Poleg

25 Za natančnejši prikaz tovrstnega pojmovanja človeške svobode glej Žižek (2005: 85-88).

26 Morda je še najbolje priznati, da svoboda „na sebi“ ne obstaja, sploh če naj bi pomenila stanje popolne družbene nevezanosti in neodvisnosti (Elias 2000: 325) ali atribut „volje“, ki ne bi bila že „dodobra“ nadzorstveno pregnetena, strukturirana (po meri dominantne kulture) in nenazadnje tudi tako ali drugače poškodovana (Jacoby 1981: 125-129). Sicer pa se zavedanje svobode (ne glede na to, ali in koliko je zavajajoče) lepi na precej raznolike subjektivne izkušnje, denimo: (a) na stanje, v katerem je posameznikovo, ,̌̌ivljenjsko občutje“ najbolj intenzivno, to vrhunsko doživetje pa se lahko navezuje na zelo različne dejavnosti, npr. na estetske, seksualne, intelektualne, verske, kontemplativne, mistične, meditativne, športne, ustvarjalne, umetniške ali ljubezenske; (b) na stanje, v katerem subjekt ne čuti pritiska verig, v katere je vklenjen (ker se je nanje že navadil), ali pa mu to dejstvo ni več tako nadležno kakor v preteklosti (Nietzsche 2005: 450-451); (c) na stanje, v katerem posameznik sodi, da ne more ravnati drugače, saj bi sicer izdal svoja najgloblja prepričanja, težnje ali vrednote; (č) na človeško „iniciativo“ (initium), tj. na zmožnost ljudi, da delajo „čudeže“, da delujejo na način, ki ustvari nekaj zares novega, popolnoma nepričakovanega, nepredvidljivega, „neskončno neverjetnega“, presenetljivega, osupljivega, šokantnega in nikoli povsem razložljivega, nekaj, kar prekinja samodejnost običajnih, uhojenih intersubjektivnih (duševnih in socialnih) procesov, saj vzpostavi neki nov začetek v redu obstoječega (Arendt 2006: 173-178). No, kot nam dan in noč pridigajo propagandisti kapitalistične vere, nas lahko radosten občutek svobode preplavi že tedaj, ko $\mathrm{v}$ privilegirani vlogi potrošniškega „kralja“ izbiramo med različnimi primerki te ali one dobrine, npr. toaletnega papirja, zobne paste, jogurta, spodnjega perila, čokolade, dezodoranta ali, še bolje, ,cenenega razkošja“ (cheap luxury). Kdor z malim ni zadovoljen ...

27 Jacoby (1981: 103) poudarja, da so prav Freudove „podtalne“ raziskave človeške duševnosti vrgle dolgo in hladno senco dvoma o obstoju avtonomnega, zasebnega, pristnega subjekta. Razkrile so namreč, da je posameznik prežet z nakopičenimi plastmi skelečih opominov in ostankov psihičnih, čutnih in erotičnih konfliktov, ki izvirajo iz medčloveških odnosov in iz 
tega pa so dosledno samonadzorovane (ali podružbljene) osebe - npr. zaradi svojega „robotskega“ obnašanja, avtomatskega odzivanja ali nepopustljive zadržanosti neredko precej nezanimive, dolgočasne ali celo odbijajoče.

Podčrtati velja, da je zmožnost samokontrole odvisna tudi od dejavnikov, na katere posameznik ni mogel (zavestno in voljno) vplivati in za katere potemtakem ne more biti odgovoren. Po drugi strani pa je jasno, da sta stopnja in usmeritev samokontrole, ki se pričakuje ali zahteva od posameznika družbeno in zgodovinsko spremenljivi. Za moderno družbo je značilno, da zahteva od posameznika izredno visoko raven stanovitnega in enakomernega (zavestnega in $\mathrm{v}$ precejšnji meri tudi nezavednega) krotenja, brušenja, obvladovanja, omejevanja in uravnavanja celotne (in v marsičem nepresojne) strukture nagonskih in emocionalnih vzgibov. Pomislimo zgolj na nadzorovanje agresivnosti. V bojevniškem srednjem veku ni bilo v ugodju, ki ga prinaša surovo, nasilno in destruktivno ravnanje, prav nič sramotnega, bolestnega ali „nečloveškega“. Nasprotno, tovrstne prakse - npr. ubijanje, pohabljanje, mučenje, preganjanje in ugrabljanje ljudi, razkazovanje telesne in vojaške premoči, maščevanje, poniževanje premaganega sovražnika in uničevanje njegovega gmotnega premoženja (npr. vinskih trt, gozdov, sadovnjakov, polj, vodnjakov, živine in gradov) - so bile ljudem (ne le pripadnikom vrhnjega aristokratskega sloja, marveč tudi meščanom in drugim statusno nižje razvrščenim pripadnikom fevdalno razparcelirane družbe) običajno v veliko veselje. Vojne, ropi, grabež, lov na ljudi in živali, umori, nasilni obračuni med sprtimi družinami ali klikami, krvno maščevanje in različne oblike telesnega kaznovanja so bili tedaj normalno „stanje stvari“, tako da je bilo življenje slehernika zelo negotovo, prihodnost pa nepredvidljiva. Vzporedno z razvojem novoveških družbenih struktur - centralizirane države, ki monopolizira uporabo legitimne fizične sile in pobiranje davkov, ter členitvijo in podaljševanjem verig medsebojne odvisnosti - so se preobražali in ,"civilizirali“"(Elias) tudi psihični aparati. ${ }^{28}$ Če odmislimo vojne, revolucije, upore, vstaje, ,nemire“ in situacije, v katerih popusti pritisk (ne)formalnega družbenega nadzora, so v modernem svetu prizori množičnega nasilja precej redki. ${ }^{29}$ Priložnosti za družbeno sprejemljivo izražanje bojevitosti ali napadalnosti so se precej razredčile. Uživanje v nasilju ali krutosti je dandanes sprejemljivo le še v sublimirani, pasivni ali polikani obliki, npr. kot zadovoljstvo za

antagonizmov med nagonskimi silami in kulturnimi omejitvami represivne družbe.

28 Za podrobnejši prikaz vloge nasilja v srednjeveškem kontekstu glej Elias (2000: 333-368).

29 Harari (2015: 373-374) opozarja, da ljudje dandanes zlahka prezrejo, v kako mirnem času živijo in koliko nasilnejši je bil svet v preteklosti: „Leta 2000 je zaradi vojne umrlo 310.000 ljudi, zaradi nasilnih zločinov pa še 520.000 ljudi. Vsaka žrtev pomeni uničen svet, uničeno družino, na smrt preplašene prijatelje in sorodnike. Vendar je z makrovidika teh 830.000 žrtev predstavljalo le 1,5 odstotka od 56 milijonov ljudi, ki so umrli leta 2000. Tega leta je v prometnih nesrečah umrlo 1,260.000 ljudi (2,25 odstotka vseh umrlih), 815.000 ljudi pa je storilo samomor (1,45 odstotka). Podatki za leto 2002 so še osupljivejši. Izmed 57 milijonov umrlih je bilo žrtev vojn samo 172.000, žrtev nasilnih zločinov pa 569.000 (skupaj 741.000 žrtev človeškega nasilja). Nasprotno pa je samomor naredilo 873.000 ljudi.“"Harari ocenjuje, da je bilo v decentraliziranih kraljevinah srednjeveške Evrope vsako leto na 100.000 prebivalcev ubitih od 20 do 40 ljudi: „Zdaj je svetovno povprečje 9 umorov na 100.000 prebivalcev na leto in večina se jih zgodi v državah, kakršni sta Somalija in Kolumbija. V centraliziranih državah Evrope se v povprečju na 100.000 prebivalcev zgodi en umor na leto.“ 
oči televizijskih in filmskih gledalcev. Vse bolj pa je, vsaj v omikanih krogih, celo opazovanje fiktivnega, še posebej pa realnega trpinčenja človeških in nečloveških živali vir nelagodja (in razlog za zgražanje). Oseba, ki odkrito uživa v tovrstnih rečeh, velja za nenormalno, moteno ali bolno (in ne le za nemoralno). Elias (2000: 351352) poudarja, da je to dolgotrajno preobražanje duševne (nagonske in emocionalne) strukture (ki pa ga mora vsak otrok ponoviti v dokaj kratkem obdobju svoje primarne socializacije) učinek precej preprostega psihičnega mehanizma, ki se imenuje pogojevanje. Družbeno nesprejemljivo udejanjanje nagonskih vzgibov in izražanje spremljajočega ugodja se bolj ali manj nepretrgoma povezujeta z grožnjo kaznovalnih reakcij, ki ustvarjajo neugodje (in druga neprijetna čustva, kot so strah, tesnoba, sram in krivda) in ki sčasoma dosežejo njegovo prevlado. ${ }^{30}$ Zunanje prisile se tako prelevijo v notranje (samoprisile); družbeni tabuji postanejo individualni; nagonski vzgibi, ki obljubljajo užitek, se bojujejo s prepovedmi, podprtimi s zagroženimi neformalnimi in formalnimi sankcijami; družbene in kulturne strukture se vtisnejo $\mathrm{v}$ posameznikovo duševnost (jaz in nadjaz), npr. v obliki (zavestnih in nezavednih) strahov, avtomatizmov in navad.

V zgodovini se je zvrstilo že nič koliko teorij o tem, kako razumeti človeško dušo in kako nadzorovati tiste njene vsebine, ki so - zaradi škodljivih moralnih, pravnih, političnih ali ekonomskih reperkusij - problematične bodisi za družbo (ali državo) bodisi za njenega nevidnega „posestnika“, npr. zato, ker mu povzročajo trpljenje ali mu otežujejo prilagajanje na zunanjo realnost. Ko gre za prastaro vprašanje, kako krotiti kulturno nesprejemljive strasti, nagnjenja, interese ali želje, marsikdo najprej pomisli na zastraševanje z negativnimi sankcijami. Toda opiranje zgolj na neformalne in formalne kazni očitno ni dovolj, in sicer ne le zato, ker so pogosto neučinkovite (obsojenca niti ne zastrašijo niti ne „poboljšajo“) ali pa so celo kontraproduktivne. Težava je navsezadnje tudi v tem, da se je kaznim mogoče tako ali drugače izogniti. Še več, zlahka je mogoče uvideti, da hujši ko je zločin (večja ko je škoda, ki jo povzroči), večja je verjetnost, da bo ostal nekaznovan (toleriran, ignoriran, nevtraliziran, racionaliziran ali celo zavidljivo nagrajen). Ta problem sicer najbolje rešuje Platonov mit o peklu, kjer zločince čaka neizogibno, večno in strahotno trpljenje (nezavidljivo trpka usoda, ki je gotovo neprimerno bolj neprijetna kakor večna smrt). A vera $\mathrm{v}$ obstoj te zlovešče onostranske kaznilnice (in celo v nesmrtnost duše ${ }^{31}$ ) je že precej

30 Zanimivo je, da tudi Beccaria (2002: 61-62) priporoča ravno pogojevanje kot ključni nadzorstveni mehanizem, ki naj z zagroženimi kaznimi kot „otipljivimi razlogi“ odvrača „duha slehernega človeka“" od kriminalnega, družbeno škodljivega in prepovedanega ravnanja. Po njegovem mnenju so izkušnje pokazale, da se ljudje večinoma ne podrejajo „stanovitnim načelom ravnanja“. In še huje, niti govorniški dar, niti bombastično pridiganje, niti „najbolj vzvišene resnice" niso zadoščale za to, da bi za dalj časa obrzdale strasti, ki jih prebujajo živi izzivi iz neposrednega okolja. Edino, kar deluje preprečevalno (odvračilno ali zastrašujoče) so „otipljivi razlogi“ (= kazni), ki „neposredno pretresejo čute in ki se venomer prikazujejo umu kot protiutež močnim vtisom delnih strasti, ki se upirajo občemu dobremu“.

31 Ideja o duši, ki čudežno preživi telo in živi še naprej, je že zelo stara. V krščanski perspektivi je ta njena nenavadna trdoživost zasluga Boga, ki jo je ustvaril, in to kot enako med enakimi (ne sicer v tostranstvu, ampak vsaj pred njihovim stvarnikom), iz česar sledi, da je tudi posvetno življenje pripadnika vrste Homo sapiens sveto. Če (in dokler) je nedolžno, nima nihče pravice, da bi mu ga odvzel (saj bi eo ipso kršil lastninsko ali vsaj avtorsko pravico Boga, ki je človeka 
oslabela, tako da sodobni nadzorniki nanjo ne morejo več resno računati. V Platonovi koncepciji hierarhično urejene duše pripada komandni položaj (raz)umu, ki naj vlada nižjim, iracionalnim, potencialno nevarnim emocionalnim silam in vzdržuje psihičnem sistem $\mathrm{v}$ funkcionalnem ravnovesju. A to ni enostavno. Treba je namreč poznati standarde, ki naj jih upošteva dušni vladar, in to ne kakršnekoli, marveč neizpodbitne, absolutne, univerzalne, resnične. Do teh pa se je zmožen dokopati le dobro izobraženi, asketski filozofski um, ki se mu slednjič - po zaslugi svojevrstne razsvetlitve, razodetja ali mistične izkušnje (ki je ni mogoče ubesediti) - razkrije transcendentna ideja (ali bistvo) dobrega (in pravičnega), ki je onkraj empiričnega mnoštva, relativnih normativnih vodil, mnenj ali konvencionalnih modrosti in ki je običajni smrtniki, priklenjeni na neizogibno delo, skrb za preživetje, svet videzov, parcialne funkcije in specializirane veščine (ali strokovne spretnosti), ne morejo uvideti. Ker ljudje večinoma nimajo oči, ki bi zmogle videti (in spoznati) resnico, jih je treba usmerjati s prepričevanjem (širjenjem vere $\mathrm{v}$ to ali ono namišljeno resničnost, npr. v obstoj posmrtnih in večnih kazni in nagrad) in, ker pač ne gre drugače, s tostransko distribucijo korenčkov in palic. To pa ima pomembne politične implikacije: ker je le filozof - kot utelešenje vrline, namreč vednosti o tem, kaj je dobro za ljudi in skupnost - tisti, ki zna in zmore pravilno obvladovati samega sebe, je hkrati tudi edina primerna oseba za vladanje drugim. V Platonovi idealni državi zatorej modri vladarji (imetniki „kraljevske veščine“ urejanja skupnih zadev in najplemenitejših duš) pravično in v interesu vseh vladajo podrejenim proizvajalcem (kmetom, delavcem, obrtnikom in trgovcem), katerih ključna naloga je, da - v režimu delitve (specializiranih) delovnih opravil - zagotavljajo nujno potrebne dobrine za zadovoljevanje življenjskih potreb

- telo in dušo - ustvaril). Na zamisel o svetosti in zatorej nedotakljivosti človeškega življenja (od spočetja do smrti) se dandanes pogosto sklicujejo zagovorniki prepovedi splava, detomora (kot njegove zapoznele variante), samomora in evtanazije. Ko gre za vprašanje (ne)dopustnosti „lepe smrti“ velja upoštevati, da ima ta način prenehanja življenja več oblik, ki terjajo posebno normativno obravnavo. Prvič, posameznik, ki hoče umreti in ki se je zmožen ubiti sam, želi zgolj pomoč, in sicer v tem smislu, da mu nekdo priskrbi sredstvo, ki mu bo zagotovilo kar najbolj zanesljivo, hitro in neboleče slovo. Drugič, posameznik hoče umreti, a se sam ne more več ubiti, zato prosi neko drugo osebo (npr. partnerja, otroka ali prijatelja), da mu naredi to zadnjo uslugo. Tretjič, posameznik, ki le še vegetira ali trpi zaradi neozdravljive bolezni, ni več sposoben privoliti v lastno smrt (poprej pa ni izrazil volje, kako naj ga obravnavajo v takem položaju), tako da je njegova klavrna usoda odvisna zgolj od drugih. Četrtič, v podobni situaciji je novorojenček, ki se rodi hudo in nepopravljivo prizadet, hkrati pa ni sposoben izbire med življenjem in smrtjo. Petič, posameznik je zmožen izraziti svojo voljo glede svojega nadaljnjega obstoja, a ga tisti, ki mu hoče odvzeti življenje, ne vpraša, kaj si želi, ali pa njegove izbire ne upošteva (ker pač sodi, da on sam najbolje ve, kaj je najbolje za osebo, ki jo kani poslati v grob). Šestič, razloček med aktivno in pasivno evtanazijo ni videti moralno pomemben, saj imata obe enak učinek; razlikujeta se le v tem, da opustitev zdravljenja podaljša čas trpljenja (kar je vse prej kot humano). Za podrobnejšo analizo dilem, ki se lepijo na (ne)dopustnost različnih tipov „blage in lepe smrti“, glej Singer (2008: 169-208). No, vse do današnjih dni pa je ohranila svoj vpliv tudi zamisel o enakosti človeških duš pred Bogom. Njene odmeve je mogoče slišati v doktrini, po kateri ima vsak človek - vsaj (in zaenkrat zgolj) na papirju - vrsto ekonomskih, socialnih, kulturnih in političnih pravic, $v$ priznavanju politične in pravne enakosti (en državljan = en glas v volilni skrinjici; vsak pravni subjekt $=$ nosilec lastninske pravice) in $\mathrm{v}$ prizadevanjih za odpravo te ali one oblike diskriminacije. 
(in kajpak za preživljanje krepostnih oblastnikov). Vidimo torej, da je osrednja poanta Platonove politične filozofije odkrito in skrajno kritično usmerjena zoper demokratsko ureditev starogrške polis (kot skupnosti enakopravnih in svobodnih državljanov, ki so upravičeni in usposobljeni za vladanje). Namreč: ker ni vsakdo zmožen voditi države, mora ta nadvse odgovorna naloga pripasti zgolj najboljšim, eliti, ki je osvobojena snovnih potreb vsakdanjega življenja - spoznala pravo vednost in zatorej tudi krepost (če se politično odločanje prepusti nevednim plebejcem, to prej ali slej povzroči splošno dekadenco, korupcijo, širjenje in poglabljanje vsakovrstnih pregreh, ki slednjič izpridijo celo duše najplemenitejših članov skupnosti). ${ }^{32}$

Platonova idealna država je ostala utopija (no, kot taka je bila bržčas tudi zasnovana). Ideja, da mora biti - v okviru duše, ki gospodovalno giblje in obvladuje telo - razum tisti, ki nadzoruje čustva in poželenja (strukturo afektov), pa je doživela vrsto kritik in modifikacij. ${ }^{33}$ Še najbolje se je obnesla kot priročni argument za utemeljevanje vsakokratnih družbenih hierarhij ali za upravičevanje izvrševanja oblasti nad inferiornimi človeškimi bitji (npr. ženskami, divjaki in reveži). Oglejmo si nekaj tipičnih primerov. Po trdoživem prepričanju naj bi bili moški utelešenje razuma, vrline in duha. Ženske pa so - kot „zmota narave“ (Aristotel), „hudičeva odprtina“ (Tertulijan) ali „nepopolni, spodleteli moški“ (Tomaž Akvinski) - neprimerno bolj iracionalne, opremljene $s$ šibkejšimi nravmi in dovzetnejše za greh (popuščanje skušnjavam), in sicer zato, ker so v mnogo večji meri zaznamovane s snovnostjo, mesenostjo, čutnostjo, čustvenostjo in intuitivnostjo. ${ }^{34}$ Zato ne predstavljajo grožnje le za moške(ga), marveč tudi za svoj lastni blagor (in duhovno odrešitev). To implicira, da je konec koncev tudi v njihovem najboljšem interesu, da se podredijo patriarhalni dominaciji in se z ljubečo požrtvovalnostjo predajo svojemu primarnemu poslanstvu (,naravnemu poklicu“), namreč vlogam soproge, gospodinje in matere. ${ }^{35}$ Po drugi

32 Za natančnejšo analizo Platonove politične filozofije glej Arendt (2006: 109-121). Za njeno umestitev v družbeni in zgodovinski kontekst glej Wood (2016: 88-102).

33 Avguštin (2003: 161-162) je boj med umom in strastjo, ki sta kajpak dve različni človeški zmožnosti, interpretiral kot spopad znotraj volje same, ki se tako znajde (razcepljena) v konfliktu med „hoteti“( velle) in „ne hoteti“( ne le ne more, npr. zaradi telesnih omejitev, nezadostnih mentalnih sposobnosti ali objektivnih zunanjih okoliščin): med močno (,svobodno“) voljo in nemočno (,nesvobodno“) voljo, ki se borita za prevlado nad posameznikovim duhom. Mnogi novoveški misleci so dokazovali, da razum ni gospodar, marveč služabnik željnosti (kot bistva človeškega bitja). Spinoza (1988: 259) trdi, da je človek suženj afektov in je zato zgolj ,,igrača usode, ki ima nad njim tako moč, da je pogostoma prisiljen slediti slabemu, dasiravno ve, kaj bi bilo zanj dobro“. Po njegovem mnenju je mogoče afekt $X$ brzdati ali odstraniti samo $z$ nekim drugim afektom $Y$, ki je nasproten in močnejši od tistega, ki ga je treba postaviti pod učinkovito kontrolo. Za celovitejši prikaz „načela zoperstavljanja strasti“ (ki se na političnem področju zrcali v doktrini delitve oblasti na različne veje) glej Hirschman (2002: 28-37).

34 Takole poroča Medeja o vročičnem sporu v njeni duši, preden umori svoje otroke: „Zla se zavedam, ki ga bom storila, v načrtih mojih pa zmaguje strast, ki smrtnim je največji vzrok gorja“ (Evripid 2000: 53-54). Za podrobnejši prikaz seksističnih predstav o ženski naravi v novoveški evropski zgodovini glej Bock (2004: 11-57).

35 Upoštevati velja, da so (družbeno in zgodovinsko spremenljive) patriarhalne strukture običajno v sozvočju z dominantnim produkcijskim načinom. Patriarhat ni ahistorična stalnica, ki bi vključevala zgolj (iz naravnih ali bioloških danosti izvirajočo) zatiralsko in izkoriščevalsko 
strani pa morajo moški odgovorno prevzeti nase breme svoje superiornosti in skrbno nadzorovati ženske (še posebej tiste, ki se štejejo za ,njihove“), in to v svoje in njihovo dobro. Posebno pozornost velja nameniti kontroli nad seksualnostjo in si prizadevati, da se bo žensko spolno poželenje ekskluzivno obesilo zgolj na košček mesa, ki se ponosno dviguje in utrujeno spušča pod pasom njenega dragega. V nepopustljivem in bojevitem naprezanju, da bi obrzdali žensko spolno poželenje, ki je bilo ožigosano kot zlo, nemoralno, nespodobno, grešno, nevarno ali bolezensko, so bile (in so še vedno) uporabljene najrazličnejše oblike propagande, vzgojnega ukalupljanja, sankcioniranja in zdravljenja (medicinskega, psihiatričnega in psihoterapevtskega). Denimo: zasmehovanje, sramotenje, poniževanje, izobčenje (ali marginalizacija), zapiranje, pretepanje, mučenje, ubijanje (npr. s sežigom, kamenjanjem, obešanjem, strelnim orožjem ali fizično silo), pohabljanje spolovil (npr. odstranjevanje klitorisa), prepoved (ali vsaj oteževanje) masturbacije (ki so jo zdravniške avtoritete stoletja štele za poglavitni vzrok hudih telesnih in duševnih bolezni), ${ }^{36}$ kontracepcije, splava in detomora, potiskanje $\mathrm{v}$ ekonomsko in statusno odvisnost od enega samega moškega (= moža) in tako dalje. Na nujnost prevlade razuma nad čustvenimi in nagonskimi silami so se sklicevati tudi panevropski (zahodni) imperialisti, ki jih je brezmejni pohlep nezaustavljivo usmerjal v vojaško osvajanje in kolonizacijo tujih ozemelj (v Novem svetu, Avstraliji, Novi Zelandiji, Tasmaniji, Afriki in Aziji), uničenje ali izmaličenje

gospostvo posameznih moških nad posameznimi ženskami. Patriarhat ima namreč praviloma tako ali drugačno institucionalno podporo. Kapitalistični patriarhat temelji na jedrni družini, hraniteljskem (klasičnem ali posodobljenem) modelu („družinske plače“, ki jo zasluži moški) in ideološko naturalizirani ločenosti (hierarhični segregaciji) javne in zasebne sfere: $v$ prvi poteka produktivno ali družbeno priznano in plačano delo, $v$ drugi pa reproduktivne dejavnosti - npr. nega, varstvo in vzgoja otrok, oskrba bolehnih in ostarelih, regeneracija psihofizičnih zmožnosti in zadovoljevanje tekočih življenjskih potreb -, ki pa se ne štejejo za „pravo delo“, saj ga (v največjem obsegu še vedno) ženske opravljajo brezplačno, zgolj ali vsaj pretežno iz ljubezni in drugih evolucijsko razvitih motivov. Za lastnike kapitala je tovrstna ureditev blagodejna, saj jim omogoča, da si z eksternalizacijo stroškov za reprodukcijo (formiranje prihodnje in servisiranje obstoječe) delovne sile, ki se gratis opravlja v zasebni sferi družinskih celic, prisvajajo večji del presežne vrednosti, ki jo ustvarijo proizvajalci. V kapitalizmu generirajo patriarhalno podrejenost in ekonomsko odvisnost žensk številni dejavniki, npr. (začasno ali trajno) izključevanje iz trga prodajalcev delovne sile, siljenje v opravljanje slabo plačnih ,atipičnih“ del (kot so mezdno delo na domu, pol- ali neformalno, prekarno, pogodbeno in projektno delo, zaposlitev s polovičnim delovnim časom ali delo v družinskem podjetju, v katerem je mož hkrati še zaposlovalec in šef), podaljšan in preslabo plačan ali prekratek in neplačan porodniški in starševski dopust, pomanjkanje cenovno dostopnih celodnevnih vzgojno-varstvenih ustanov (s strokovno usposobljenim osebjem) in tako dalje. Za natančnejšo analizo (post)modernega patriarhata glej Burcar (2015: 5-42).

36 Ryan in Jethà (2013: 239-248) opozarjata, da je bila masturbacija dolga stoletja dopustna le kot oblika zdravljenja nenavadne bolezni, katere simptomi (npr. tesnobnost, nespečnost, razdražljivost, živčnost, erotično sanjarjenje, občutek teže v trebuhu, endemi v spodnjem medeničnem predelu in vlaženje nožnice) so sumljivo podobni znamenjem spolne prikrajšanosti in kronično nepotešenega vzburjenja. To terapijo - ,vulvične masaže“, ki privede do „živčnega paroksizma“ - so za plačilo opravljali večinoma moški zdravniki. „Pacientk“, spolno frustriranih spodobnih žensk, vsekakor ni primanjkovalo (v neki medicinski knjigi o zdravju in boleznih žensk, ki je izšla leta 1873, je priobčena ocena, da je tedaj potrebovalo tovrstne terapevtske usluge približno 75 odstotkov Severnoameričank). 
tamkajšnjih staroselskih kultur, surovo podjarmljenje, zasužnjevanje, izkoriščanje, zatiranje, ropanje, plenjenje, izsiljevanje, poniževanje, iztrebljenje, mučenje in pobijanje manjvrednih, divjaških, inferiornih človeških bitij. Vrli zahodnjaki so svoje zločinsko nasilništvo in pridobitništvo (prilaščanje in bogatenje), ki mu v človeški zgodovini ni para, kajpak moralno utemeljevali (,pozor, gre nam za vaše dobro“), najpogosteje kot „breme belega človeka“, ki se mora odpraviti v daljne in neznane kraje, da bi svoje civilizacijsko zaostale (ali celo zaustavljene) brate in sestre osrečil z dosežki znanstvenega, tehničnega, tehnološkega, medicinskega, političnega, pravnega, umetniškega in nasploh kulturnega napredka, za posladek - ki naj vsaj ublaži tostranski pekel kapitalistične eksploatacije in „destruktivne kreativnosti“ - pa še z edino pravo in resnično (univerzalno) religijo, ${ }^{37} \mathrm{ki} \mathrm{z}$ velikim pompom poudarja (božjo in človeško) ljubezen, sočutje in dobrodelnost.

Moralisti, teologi, filozofi in učenjaki so si stoletja belili glave z vprašanjem, kako obrzdati pregrešne in škodljive strasti, npr. pohlep (nenasitno slo po denarju, razkošju in posesti), koristoljubje (pripeto na trgovanje, oderuštvo ali bančništvo), oblastiželjnost (libido dominandi), slavo- ali častihlepje, nečimrnost, pohoto (spolno slo), skopuštvo, ambicioznost, napuh ... Skupni imenovalec problematičnih duševnih nagnjenj (ali teženj), ki jim je treba natakniti uzdo, je bila skoraj po pravilu - sebičnost. Z vzponom kapitalizma, katerega temeljni resurs je sicer zaupanje vlagateljev v prihodnost (v brezmejno gospodarsko rast, cilj vseh ciljev modernih industrijskih družb), pa so se te reči postavile na glavo. Nekdanje (zasebne) pregrehe so se prelevile v (javne) vrline, strasti pa so preobrazile v ,interese“. V sebičnosti (zasledovanju lastnih, najpogosteje materialnih interesov, od katerih je v blagovni ekonomiji pač neposredno ali posredno odvisna večina drugih hotenj ali želja) ni več

37 Cena, ki so jo morali plačati domačini - nemirni in divji ljudje, napol hudiči, napol otroci (kot jih je opisal Rudyard Kipling) - za materialne in duhovne darove zahodnega uma, je bila visoka (in se še vedno odplačuje, z obrestmi). Zgolj za grobo ilustracijo: V dvajsetih letih po Kolumbovem „odkritju“ Amerike so pomrli skoraj vsi prvotni prebivalci Antilov, španski konkvistadorji pa so to praznino zapolnili z uvozom afriških sužnjev (katerih število v Ameriki se je do 19. stoletja povzelo na približno 10 milijonov). Od 80 milijonov prebivalcev, ki so leta 1500 živeli v obeh Amerikah, jih je sredi 16. stoletja ostalo le še 10. Prebivalstvo Mehike je na predvečer osvojitve štelo približno 25 milijonov, leta 1600 pa zgolj en milijon. To neznansko, genocidno uničenje lokalnega življa je bilo posledica pobijanja, izčrpanosti (zaradi neznosnih delovnih razmer in obremenitev), morilskih davkov, podhranjenosti, zasužnjevanja, bolezni, izgube volje do življenja, zavračanja razmnoževanja (zaradi predrugačenih, ponižujočih in nevzdržnih življenjskih okoliščin) in uničenja tradicionalnega družbenega tkiva (glej Todorov 2014: 163-178). Harari (2015: 283-284) ugotavlja, da se je število staroselcev v Avstraliji in Novi Zelandiji zmanjšalo za 90 odstotkov, potem ko so jim evropski priseljenci odvzeli večino rodovitne zemlje (preživeli domačini pa so trpeli strahotno rasno zatiranje). Še hujša usoda je doletela domačine na Tasmaniji, katere prebivalstvo je 10.000 let preživelo v popolni osami: sto let po prihodu Cookove oprave, ki je položila temelje za britansko zasedbo jugovzhodnega dela Tihega ocena, so civilizirani Evropejci iztrebili prav vse. V obdobju velike bengalske lakote (1769-1773), ki je bila posledica porazne gospodarske politike (zgolj za čim hitrejše gmotno okoriščanje zainteresiranih) britanskih vladarjev, je umrlo približno deset milijonov (= tretjina) prebivalcev tedaj najbogatejše indijske province. Za zgoščen prikaz grozot, ki jih je zakrivila panevropska civilizacija (in moralnih alibijev, s katerimi jih je skušala upravičiti), glej Galeano (2011: 33-56). 
po novem prav nič slabega, zavržnega ali graje vrednega. Sebičnež je zdaj spoznan - po zaslugi nevidne tržne roke (skrbno zavarovane $\mathrm{z}$ jekleno pestjo centralizirane nacionalne države) - za altruista. Gonja zasebnih podjetnikov za čim večjim dobičkom (ki kajpak ne izvira le iz individualne pohlepnosti, marveč tudi iz strahu pred grozečo konkurenco) namreč koristi vsem in povečuje skupno bogastvo, wealth of nations. Še več, v luči predrugačenih novoveških vrednot se šteje ravno bogataš za najbolj koristnega, dobrohotnega in zatorej tudi hvalevrednega člana družbe, tako rekoč za utelešenje morale in ogledalo kreposti, ${ }^{38}$ saj s stanovitno akumulacijo kapitala poganja kolesja gospodarske rasti, ta pa povečuje kolač, od katerega imajo prej ali slej koristi prav vsi (čeravno ne vsi v enaki meri), nazadnje celo bedniki, ki se drenjajo $\mathrm{v}$ zatohlih kleteh družbene piramide. $Z$ drugimi in nemara jasnejšimi besedami: pravo in najpomembnejše bogastvo kapitalistične družbe so njeni bogataši, novodobne svete krave, materialna in duhovna avantgarda par excellence vseh delovnih ljudi in občanov. Pod bleščavimi žarometi kapitalističnega nazora je kot najhujši greh ožigosana „lenoba“ (npr. zavračanje mezdnega suženjstva, storilnosti, produktivnosti, učinkovitosti in podjetnosti ali prepočasno, ne dovolj zagnano izpolnjevanje ukazov gospodarjev, ki podrejenim in odvisnim delavcem „dajejo“ plačano zaposlitev), ${ }^{39}$

38 Glej Adorno (2007: 207-210). Za razvoj pojma „interes“ kot krotilca „divjih“ (agresivnih ali razdiralnih) strasti, in sicer na ta način, da jih poveže s preudarnim, premišljenim ali razumnim samoljubjem, ki jih požlahtni, zmehča, zgladi, obrusi in usmerja, zaradi česar postanejo bolj predvidljive, stanovitne, potrpežljive in umirjene, glej Hirschman (2002: 37-51). Pomen besede „interes“, ki se je prvotno nanašala na „plačilo obresti“ ali „odškodnino za zamudo pri odplačilu dolga" (Graeber 2014: 494-496), se je že kmalu skrčil na zasledovanje materialne koristi ali dobička in nasploh na posameznikovo prizadevanje za izboljšanje lastnega položaja s povečevanjem premoženja. Je torej materialni interes - težnja po bogatenju (in izogibanju revščini) - tisti ključni motiv, ki ima zadnjo besedo v duševni ekonomiji? Ne nujno. Pogosto je zgolj sredstvo za „,nekaj več“? Za kaj? Za mnoge mislece je najpomembnejši človekov vzgib „nečimrnost“ (Adam Smith) ali „,amour propre“ (Rousseau 1993: 64-65), namreč (že po svoji naravi brezmejna) želja, da si opažen in deležen pozornosti, priznanja, ugleda, naklonjenosti, odobravanja, simpatije, ugajanja, časti, spoštovanja, slave ali občudovanja. Za natančno analizo tovrstnih (,timotičnih“) motivov glej Sloterdijk (2009: 34-42).

39 Lenoba - recimo to, da „prav ničesar ne delaš“, da „,ne daš absolutno nič od sebe“ ali da „Zapravljaš čas v tri krasne“ - je pojav, ki ga le redko srečamo v vsakdanjem življenju. Koch (2013: 44-47) poudarja, da služi grajanje - v kontekstu vsiljevanja etike dela (kot temelja ali jamstva posameznikovega dostojanstva, spoštovanja in samouresničevanja) in disciplinskega ideala „pridnega“ (ekonomsko uporabnega in politično krotkega) človeka - predvsem kot bojni klic, normativni poziv vsem državljanom, naj upravičijo svoj obstoj v kapitalističnem sistemu z družbeno priznano dejavnostjo. Vztrajati v stanju „lenobne“ nedejavnosti (popolne umirjenosti in sproščenosti) je za tipičnega sodobnika pravzaprav precej težavno, naporno opravilo, pogosto celo bolj od ,pravega“ dela. Razlogov za to je več. Delodajalci si prizadevajo kar najbolj skrčiti čas, v katerem delavec zgolj „miruje“. Od zaposlenega se zahteva, da dela neprestano (in pospešeno): ko zaključi opravilo $\mathrm{X}$, se mora lotiti naloge $\mathrm{Y}$, ne pa čakati na nov X. In še več, od delavca se pričakuje „najboljša storitev v najkrajšem času“, bliskovita odzivnost, kameleonska prilagodljivost in prevzem odgovornosti za lastno učinkovitost. Ločnica med delovnim in prostim časom je vse bolj zabrisana. Sodobna informacijska in komunikacijska tehnologija posamezniku omogoča, da dela tako rekoč kjerkoli in kadarkoli, npr. doma, na ulici ali plaži, v avtomobilu ali restavraciji, med kosilom ali nakupovanjem, $\mathrm{v}$ postelji ali na straniščni školjki. Ker kronično zmanjkuje časa za dejavnosti, ki niso „delo“, 
zločin vseh zločinov pa je nespoštovanje zasebne lastnine vladajočega razreda. Kapitalistična etika je pravzaprav sila preprosta. Proletarcem (osebam, ki so odvisne od prodaje svoje delovne sile, prirojenih in pridobljenih psihofizičnih zmožnosti) nalaga le dve temeljni dolžnosti: delaj za denar in kupuj potrošniško blago (komercialne izdelke in storitve). Tradicionalna morala je bila nedvomno dosti bolj stroga in zahtevna (in je bila prav zato za marsikoga celo pretrd oreh), saj je od naslovnikov terjala omejevanje in premagovanje sebičnih teženj, glavno nagrado za naporno odrekanje (ali odlašanje z zadovoljevanjem želja) pa je previdno postavila v posmrtno, onostransko življenje. Kapitalistična morala obljublja - in za nameček še medijsko non stop propagira in razkazuje - rajsko življenje že na tem planetu in pred smrtjo. Vrata v zemeljski paradiž se avtomatično odprejo vsakomur, ki je dovolj sebičen, pohlepen, grabežljiv, ,destruktivno kreativen“, brezkompromisen, iznajdljiv, izkoriščevalski, pretkan, inovativen, nesočuten, agresiven, prevarantski, podkupljiv ali še kako drugače sposoben, da $\mathrm{v}$ čim krajšem času zasluži čim več denarja, te dobrine vseh dobrin, ki ima poleg tega še to prednost, da uživa splošno zaupanje, ne zaudarja in ne razkriva svojega porekla.

Kapitalistična etika dela in nakupovanja je že „lep“ čas dojeta in prakticirana kot nekaj scela samoumevnega (in celo močno zaželenega). Sprva pa le ni šlo vse tako gladko. Vladajoči - zasebni in javni gospodarji - so morali vložiti precej represivnega in propagandnega truda, da se je stvar prijela: da so se ljudje navadili na delovne in potrošniške prakse v skladu s funkcionalnimi imperativi kapitalističnega gospodarstva (in industrijske, na disciplini utemeljene moderne družbe). ${ }^{40}$ Ko to ni več problem, se posameznik običajno prej ali slej znajde $\mathrm{v}$ živem pesku začaranega kroga. Želi si imeti čim več denarja, da bi lahko trošil ne le tisto nujno, kar potrebuje njegov organizem za normalno in spodobno preživetje (ali vsaj za odlaganje srečanja s smrtjo kot absolutnim gospodarjem vsega živega), marveč predvsem „sanjske“ - simbolno in statusno najbolj cenjene (in zatorej tudi drage) - dobrine. Zato mora čim več ali vsaj „,dobro“ delati. Na delovne obremenitve pa se rade prilepijo telesne in psihične neprijetnosti, ki jih mora kapitalistični „udarnik“ kompenzirati ali nevtralizirati s komercialnimi izdelki ali storitvami, ki seveda niso zastonj. In tako naprej, brez konca in kraja. Zato ni presenečenje, da - dandanes resda ne več ravno pogoste in neredko

ga je treba izkoristiti čim bolj ekonomično ali racionalno. To pa pomeni, da mora posameznik v prostem času v zgoščeni obliki vsrkati čim več doživetij ali dražljajev. Zato ni čudno, da predstavlja „brezdelje“ za vročično nemirne ljudi precejšen problem. In da se na trgu ponuja kalejdoskop komercialnih storitev, ki izmozganim herojem dela obljubljajo vsaj kratkotrajno sprostitev, „prezračenje glave“, „pašo za možgane“ ali „duševno umirjenje“, pogosto z jasnim namigom, da bo previdno odmerjena doza „lenobe“ koristila njihovi ustvarjalnosti, storilnosti in produktivnosti.

40 Lafargue (1972: 121) je navajenost ljudi na mezdo delo interpretiral kot simptom resne duševne motnje, in sicer ,čudne norosti, ki je obsedla delovne razrede v državah, kjer vlada kapitalistična civilizacija“. Ta bizarna duševna aberacija - namreč „ljubezen“ ali „neizmerna“ in celo „smrtonosna“ strast do dela (dejavnosti, ki jo moralisti, duhovniki in ekonomisti za nameček vztrajno prikazujejo kot sakrosanktno vrednoto) - povzroča trdožive individualne in socialne probleme, bedo, trpinčenje in izčrpavanje ljudi. Za zgoščen prikaz psihičnih in fizičnih nadlog, ki mučijo delavce v postmoderni, informatizirani, visokotehnološki, čedalje bolj stresni kapitalistični ekonomiji glej Rifkin (2007: 293-303); Cohen (2011: 6-13). 
dvomljivo iskrene - kritike „pretiranega“ potrošništva, podkletenega z romantičnim etosom, največkrat izzvenijo $\mathrm{v}$ prazno (ali so rokohitrsko zavrnjene kot poniglava ali norčava provokacija). To pa velja žal tudi za kritike $v$ oči bijoče obsedenosti (ali celo zasvojenosti) s heteronomnim delom, ki je že (pre)dolgo ne le absurdna, marveč naravnost groteskna, sploh če upoštevamo osupljiv znanstveni in tehnološki napredek, ki je neznansko povečal produktivnost človeškega dela. A to in abstracto nesporno razveseljivo dejstvo $\mathrm{v}$ kapitalističnem kontekstu ne učinkuje kot blagoslov, marveč kot permanentna in celo čedalje hujša grožnja za vse bolj preplašene in negotove, zato pa tudi zgledno podredljive, ubogljive in pridne "srečneže“ (z neverjetno gibkimi hrbtenicami), ki imajo privilegij, da so izkoriščani in poniževani. V tej luči potemtakem niti ni čudno, da se bedniki v zmedenem postmodernem času z vsemi silami borijo za delo - in to $v$ razmerah podganje medsebojne konkurence in že vnaprej izgubljene tekme s ,pametnimi“ in ,neumnimi“ stroji -, ne pa proti tej nadlogi in torej za skrajšanje delovnega časa, enakomerno porazdelitev neodpravljivih ekonomskih nujnosti in povečanje „kraljestva svobode“ (Marx 1973: 913-914). ${ }^{41}$

\section{SKLEPNE PRIPOMBE O MOTENIH IN NORMALNIH DUŠAH}

Razmerja (ali interakcije) med duševno motnjo in kriminalnim vedenjem so raznovrstna in variabilna, navsezadnje tudi zato, ker so njune družbeno veljavne definicije bolj ali manj relativne, spreminjajoče se $\mathrm{v}$ času in prostoru. Povezav, ki se tkejo med njima, je nič koliko. Recimo, zgolj za najbolj grobo ilustracijo: (a) duševna motnja (npr. frustracija, ponižanje, jeza, zamera, ljubosumje, sovraštvo ali pohlep) vodi v zločin; (b) kaznivo dejanje izzove duševno motnjo (npr. travmo, strah, tesnobo, žalost ali maščevalnost); (c) zaradi kazenske sankcije, ki sledi kriminalnemu vedenju, občuti obsojenec duševno motnjo. Če je posameznik resno duševno moten, in sicer zaradi bolezni, ki je in abstracto psihiatrično pripoznana in (v konkretnem primeru) izvedensko prepoznana, za svoje škodljivo ravnanje ni kaznovan, če sodnik oceni, da sta eo ipso suspendirani njegova prištevnost in odgovornost. Vsaj v luči modernega

41 No, priznati je treba, da imamo opraviti s problemom, ki nikakor ni nov. Diagnosticiral ga je že Lafargue (1972: 149), in sicer v slovitem pamfletu z zgovornim naslovom Pravica do lenobe: „Če bi si delavski razred izkoreninil iz srca pregreho, ki mu vlada in ponižuje njegovo naravo, in se dvignil s svojo strašljivo silo, vendar ne zato, da bi zahteval Človekove pravice, ki so samo pravice kapitalističnega izkoriščanja, ali Pravico do dela, ki je zgolj pravica do bede, marveč zato, da bi skoval neizprosen zakon, ki bo slehernemu človeku prepovedal delati več kot tri ure na dan, potem bi Zemlja, stara Zemlja, vzdrhtela od veselja, zakaj začutila bi, da se na njej poraja novi svet ... Ampak, ali je sploh mogoče zahtevati, naj takšno neizprosno odločnost izrazi proletariat, ki ga je izpridila kapitalistična morala?" Resnici na ljubo velja poudariti, da so se delavci dejansko, tako in drugače, upirali mezdnemu delu in z njim povezanemu kapitalističnemu gospostvu (glej npr. Graeber 2013: 59; Bembič 2012: 45-49; Heinrich 2019: 7-9; Lebowitz 2014: 89-96; Berardi 2013: 31-72), vendar so bili doslej vselej poraženi, in to ne le zaradi surove državne represije in izjemno obsežnega globalnega bazena razpoložljive delovne sile, marveč tudi po zaslugi dosežkov neverjetnega tehnološkega napredka, s katerimi upravljajo vladajoči v gospodarstvu (in zatorej tudi v družbi). Za klasično kritiko ideje, da je napredek znanosti in tehnike sopomenka za napredek človeštva in njegovih članov, glej Rousseau (1993: 88-93), za njeno posodobljeno verzijo glej Harari (2015: 382-385). 
prava se namreč šteje, da je treba psihiatrične bolnike zdraviti, ne pa grajati in še drugače negativno sankcionirati. Po drugi strani pa so tudi obsojeni storilci kaznivih dejanj pogosto deležni terapevtske obravnave, katere cilj je odpraviti ali omiliti njihovo - prirojeno, pridobljeno ali samoustvarjeno - kriminalno dispozicijo in jih v reciklirani (normalizirani, podružbljeni, prevzgojeni, korigirani ali „poboljšani“) obliki ponovno vključiti v „svobodno“ družbeno okolje. Toda v vsakdanjem življenju velikokrat ni niti najmanj jasno, kdo je do te mere patološko moten, da si zasluži primarno - medicinsko, psihiatrično ali psihoterapevtsko - zdravljenje (ki pa ga neredko spremljajo tudi večji ali manjši odmerki kaznovalnih primesi, vključno z neformalnimi sankcijami in celo stigmatizacijo). In še več, dokaj kontroverzno je tudi to, katere duševne manifestacije (in njihove subjekte) naj sploh dojamemo in obravnavano kot „zares zdrave“ ${ }^{42}$ in torej ne le „normalne“ $v$ tem smislu, da so bodisi statistično prevladujoče bodisi kulturno pričakovane (ali oboje hkrati). ${ }^{43}$

Zdravje - ne le psihično, marveč tudi telesno (kolikor ju je sploh smiselno razlikovati) - in bolezen nista razmejeni s strogo, neprepustno ločnico, zato je zelo sporno, kdaj neka normalna motenost postane bolezenska (in obratno). Dodaten problem je $\mathrm{v}$ tem, da utegne biti neko duševno stanje ali nagnjenje škodljivo in patološko zgolj za druge, ${ }^{44}$ ne pa tudi za posameznika, ki ga občuti (in pretvarja $\mathrm{v}$ svoje delovanje). Nemara najbolj razvpit zgled tovrstnih zadreg je psihopat, strašljiv lik, čigar osebnost označuje niz problematičnih lastnosti, kot so odsotnost moralnih

42 Spinoza (1988: 295) opozarja, da kak predmet tako zelo aficira ljudi, da so prepričani o njegovi navzočnosti, čeprav je dejansko odsoten: „Če se to primeri človeku, ki ne spi, pravimo, da blazni ali da se mu je zmešalo. Za blazneže veljajo tudi strastno zaljubljeni ljudje, ki ponoči in podnevi sanjajo samo o svoji ljubici ali priležnici, ker navadno vzbujajo posmeh. A skopuh, ki misli samo na svoj dobiček in denarce, častihlepnež, ki misli samo na slavo, itn. ne velja za blazneža, ker je po navadi nadležen in po splošni sodbi sovraštva vreden. V resnici pa so lakomnost, častihlepje, pohota itn. vrste blaznosti, čeprav jih ne štejejo med bolezni.“

43 Videti in slišati je, da ljudje dokaj hitro pripišejo osebi, ki je tako ali drugače odklonska (v svojem čustvovanju, razmišljanju, odločanju, vrednotenju ali delovanju), etiketo, ki nedoumno kaže na njeno duševno motenost, npr. norost, prismuknjenost, trčenost, blaznost, paranoidnost, zblojenost in tako dalje. Običajno je pač tako, da se posameznik (,jaz") ali dominantna skupina („mi“ kot organizirana normalnost ali celo nedolžnost) dojema kot utelešenje duševnega zdravja in merilo, s katerim presoja bolnost drugih. Kundera (2008: 134-135) pa opozarja, da vendarle obstaja psihična prvina, s katero se nihče ne ponaša, a je vseeno univerzalna. To je neumnost, ki je po njegovem mnenju neozdravljiva, neodpravljiva, omniprezentna, neodtujljiva spremljevalka človeške narave. Ni torej izjema, napaka ali naključje. Ni pomanjkljivost, ki bi jo bilo mogoče korigirati, sanirati ali kompenzirati z izobrazbo. Svoj dom ima v dušah bedakov, genijev in onih - večine človeških bitij - vmes. To pomeni, da prebiva v „duši vseh človeških stvari“. In da se ta „krhka in sramežljiva vila“, kot jo prizanesljivo označi Kundera, „odlično prilega dobremu in zlu, znanju in nevednosti“.

44 Ryan in Jethà (2013: 122) opozarjata na že dolgo pozabljeni bolezni, ki so ju svoj čas imenovali „drapetomania“ in „dysaethesia aetiopica“. Daljnega leta 1851 ju je identificiral dr. Samuel Cartwright, tedaj vodilna avtoriteta za zdravstveno oskrbo črncev v Louisiani in najvplivnejši mislec gibanja, ki se je zavzemalo za ohranitev suženjstva. V razpravi Bolezni in posebnosti črnske rase je „drapetomanio“ opisal kot bolezen, ki povzroči, da suženjski delavci na plantažah nočejo več pokorno služiti svojim belim gospodarjem. Za drugo bolezen pa naj bila značilna ,čutna in zaznavna otopelost“, ki so jo laični nadzorniki sužnjev sicer obravnavali kot „malopridnost“". 
čustev (npr. krivde, sramu, sočutja, obžalovanja in kesanja), nedovzetnost za učinek negativnih sankcij (ki se najbrž navezuje na nezmožnost učenja na podlagi preteklih izkušenj), neiskrenost (lažnivost kot nasprotje resnicoljubnosti), čustvena nezrelost, impulzivnost (pomanjkljiva samokontrola), nizka stopnja prenašanja frustracij, nezmožnost vzdrževanja (ali zavračanje) trajnih in kakovostnih medčloveških (prijateljskih in ljubezenskih) razmerij, nepoštenost, manipulativni in instrumentalni odnos do soljudi (ki jih obravnava zgolj kot orodje za doseganje lastnih ciljev), egocentričnost, nepopustljiva zasidranost $\mathrm{v}$ sedanjosti, naglo spreminjajoča se razpoloženjska stanja, kronično antisocialna „drža“ (neupoštevanje veljavnih pravil igre), nagnjenje k takojšnji zadovoljitvi želje, neodgovornost, izredno močna volja do moči (nad drugimi), nezanesljivost in nezainteresiranost za terapevtsko pomoč, po drugi strani pa tudi precejšnja kreativnost, inteligentnost, očarljivost ali talentiranost. To, kar marsikoga še posebej bega ali čudi, ko ima opravka s posameznikom, čigar osebnost je videti „psihopatska“ ali „,antisocialna“ (v preteklosti so tovrstne človeške figure dojemali kot „moralne imbecile“), je dejstvo, da je moteč le za druge, ne pa tudi zase. V očeh psihopata namreč njegov življenjski slog ni le neproblematičen, marveč je celo bolj ali manj osrečujoč, ${ }^{45}$ prijetno vznemirljiv, pregneten $\mathrm{z}$ užitki, ki izvirajo iz neodgovornega, brezskrbnega, svobodnega zasledovanja in uresničevanja želja (brez nekega koherentnega in konsistentnega življenjskega načrta in onkraj kulturno predpisanih shem, v katerih se gibljejo - in iščejo smisel svoje eksistence, pot ali bližnjico do samouresničitve, ontološko varnost in dobro ali vsaj znosno subjektivno počutje - normalni člani družbe).

Mnenja strokovnjakov o tem, katere značilnosti mora imeti oseba X, da ji je mogoče (onkraj sence dvoma) pripisati zloslutno oznako „psihopat“, niso enotna, to pa se odraža tudi v ocenah števila tovrstnih posameznikov v prebivalstvu. A nesporno se zdi vsaj to, da psihopati niso v večini (čeravno so nekateri psihologi prepričani, da so nadpovprečno zastopani na vodilnih položajih, zlasti v gospodarstvu ${ }^{46} \mathrm{npr}$.

45 Singer (2008: 314-316) opozarja, da izjavam oseb, ki so diagnosticirane kot psihopati, kajpak ne kaže zaupati zgolj na „lepe oči“ (ali a priori), saj gre vendar za notorične manipulatorje in prepričljive lažnivce. Njihova poročila, ki pričajo, da so povsem zadovoljni z lastnim načinom življenja, pa je mogoče pospremiti tudi z očitkom, češ da sploh ne vedo, kaj je dejansko „prava človeška srečnost“", saj niso zmožni uživati v tako zelo hvalevrednih rečeh, kot so npr. urejeno družinsko življenje, trdo in pošteno delo ali zakonito in legitimno doseženi uspehi na poslovnem in poklicnem področju. A ta argument lahko uporabi tudi psihopat: „Normalneži, hej, kako pa vi s tolikšno gotovostjo veste, da ste resnično srečni, če pa sploh ne zmorete doživljati ali občutiti mojih duševnih stanj in procesov, ki so zatorej za vas popolna izkustvena neznanka, hedonistična španska vas ali eksistencialna uganka par excellence?" Maslow, slavni severnoameriški humanistični psiholog in avtor teorije o piramidni strukturi človeških motivov (na vrhu katere žari potreba po samouresničitvi, katere zadovoljitev je speta z ,vrhunskimi doživetji“" srečnosti), bi psihopatove ugovore bržčas mahoma zmlel, in to celo z levo roko: „Moj retrospektivni vtis je, da živijo ljudje z največjo mero humanosti večino svojega časa takšno življenje, ki bi ga lahko imenovali vsakdanje (ordinary) - nakupujejo, jedo, so vljudni, razmišljajo, ko izbirajo med črnimi ali rjavimi čevlji, gledajo neumne filme, berejo lahkotno literaturo“" (navedba v Jacoby 1981: 119).

46 Zdi se, da tovrstna mnenja, tudi če so deloma utemeljena, prezrejo strukturno logiko kapitalistične ekonomije in zasebnih podjetij kot njenih osrednjih akterjev. Rezultat je personalizacija (Personalisierung), namreč redukcija družbenih struktur na zavestno in voljno delovanje 
v korporacijah, finančnem sektorju in združbah konvencionalnega organiziranega kriminala). In prav gotovo jim ne moremo pripisati odgovornosti za najhujše oblike zla in krivic, ki se trdoživo pojavljajo v družbenem tkivu. Neznanska in raznolika gmota družbene, človeške in ekološke škode je namreč neposredno ali (še pogosteje) posredno povezana $\mathrm{z}$ delovanjem posameznikov, ki so psihično bolj ali manj normalni in nikakor niso patološko moteni. To velja tako za škodo, ki je posledica kršitev veljavnih predpisov, kakor tudi za še neprimerno večjo škodo, ki izvira iz zakonitega ravnanja - močnih in šibkih, vladajočih in vladanih ali oblastno nadrejenih in podrejenih - družbenih akterjev (ločnica med dopustnim in nedopustnim je kajpak marsikje skrajno zamegljena, neverjetno raztegljiva ali že scela zabrisana). Ko se obravnavajo situacije, v katerih so pripravljeni popolnoma (in celo zastrašujoče) normalni posamezniki storiti nasilna in kruta dejanja, se pogosto omenjajo šokantni rezultati Milgramovih eksperimentov, ki so pokazali, kako daleč so pripravljeni iti običajni ljudje, če jim morilsko ali destruktivno vedenje ukaže (in zanj prevzame odgovornost) avtoriteta, ${ }^{47}$ ali pa se pod lupo znajdejo notorični zločinci nacistične

posameznikov. Na ta način je resda mogoče dokaj hitro najti „dežurne krivce“ za gigantsko škodo, ki je posledica normalnega delovanja brezimnega kapitalističnega stroja, npr. brezčutne podjetnike, vampirske bančnike ali lakomne špekulante, tj. poslovneže, ki jih žene zgolj čez- ali nezmerna sla po dobičku. Vendar pa je treba upoštevati, da je kapitalist (denarni, trgovski ali industrijski), ki in kolikor deluje v skladu s svojo vlogo, le utelešenje, „karakterna maska“ ali poosebljenje (Personifikation) kapitala, človeški lik, ki mora slediti racionalnosti, kakršno mu vsiljujejo prevladujoča ekonomska razmerja in tržna konkurenca, ki mu grozi s propadom. Zato se mora gnati za čim večjim dobičkom (tudi še sam, po svojem značaju, morda ni pohlepen ali obtežen še s kakšno drugo moralno hibo), si prizadevati za povečevanje produktivnosti, uvajati novo tehnologijo, posodabljati organizacijo produkcije in tako dalje (glej Heinrich 2013: 202203). Kapitaliste je potemtakem nesmiselno grajati, ker ne skrbijo za odpiranje novih delovnih mest, ukinjajo nedobičkonosno produkcijo, selijo tovarne na območja s cenejšo in ubogljivejšo delovno silo, pritiskajo na države, naj jim zagotovijo „prijazno“ poslovno okolje ... Njihovo primarno poslanstvo je v tem, da $\mathrm{z}$ vloženim ali založenim denarjem zaslužijo še (ali čim) več denarja in da ponavljajo to elementarno „lekcijo“ (ustvarjati in si prilaščati presežno vrednost ter jo znova preobražati v kapital), dokler se to jim pač splača. Delovna sila in naravni viri so zgolj sredstva za doseganje tega cilja vseh ciljev, edinega smotra kapitalistične ekonomije.

47 Podčrtati velja, da poskusne osebe večinoma niso uživale, ko so poslušno in v nasprotju z lastnimi moralnimi prepričanji izpolnjevale ukaze, ki jim jih je dajala zanje legitimna (v tem primeru ,Zgolj“ znanstvena) avtoriteta. Nasprotno, mnogi so pri tem zelo trpeli (glej Vodovnik 2010: 50-52). To pa velja še toliko bolj za posameznike, ki so bili kot vojaki priče in izvajalci realnega nasilja. Galimberti (2011: 330) opozarja, da so skoraj tretjino izraelskih žrtev v vojni leta 1973 povzročile bolezenske težave psihične narave, čeprav je trajal spopad le nekaj tednov: „Neka raziskava o drugi svetovni vojni je ugotovila, da je 98 odstotkov vojakov, ki so preživeli dva meseca nepretrganih bojev, utrpelo bolezenske duševne poškodbe; nekateri so naredili samomor, drugi so potrebovali dolgotrajno zdravljenje ali pa so imeli trajne težave z vključevanjem v družbo. Zanje se vojna nikoli ni končala." Klasični oboroženi spopadi so imeli praviloma svoj začetek in konec, čas vojne in čas miru, točko, v kateri je posameznik postal vojak, in točko, ko si je zopet nadel civilna oblačila. Postmoderna - permanentna in globalna vojna proti terorizmu je $\mathrm{v}$ tem pogledu pomenljiva posebnost. Recimo: upravljavec dronov, ki ubija na daljavo in ne da bi bil pri tem tudi sam izpostavljen grožnji, da bo ubit, vstopa v vojno in izstopa v mir vsak delovni dan. Ko je v službi, se vojskuje, ko mine delovni čas, pa se vrne v topli mir družinskega ognjišča. Osem ur ubija in uničuje sovražne druge, osem ur pa se ukvarja z blizkimi osebami, ki jih ima rad. Njegovo življenje poteka v dveh moralno strogo ločenih 
Nemčije, ${ }^{48}$ npr. Adolf Eichmann (nadzornik in upravljavec „dokončne rešitve judovskega vprašanja“), vodje koncentracijskih taborišč ali vojaki, ki so mučili in streljali (zanje) nenevarne, nebogljene in nedolžne civiliste. $V$ tovrstnih primerih smo skoraj po pravilu priče naslednjemu vzorcu: (a) manjšina se vselej upre sodelovanju pri zločinskih dejavnostih, in sicer ne glede na konkretne okoliščine in morebitne negativne posledice; (b) znatna večina konformistično, čeravno bolj ali manj mlačno (brez opazne gorečnosti ali globoke predanosti), sledi liniji najmanjšega odpora in ubogljivo naredi to, kar ukažejo (ali pričakujejo) nadrejeni, npr. iz brezbrižnosti do žrtev, preudarnosti (racionalnega tehtanja plusov in minusov alternativnih opcij), solidarnosti s tovariši, navajenosti na poslušnost (ali na disciplino), lojalnosti (ali nagonskega in globoko ukoreninjenega spoštovanja) do avtoritete, občutka dolžnosti, strahu pred sankcijami ali zaradi identitetne ljubezni (do naroda, domovine, vere ali družine); (c) manjšina posameznikov na drugem koncu Gaussove krivulje pa se nasilju preda z opaznim navdušenjem, kot da bi že komaj čakali, da se bodo znašli v položaju, v katerem bo sproščanje nizkotnih vzgibov ne le dopustno, marveč celo moralno „dobro“. ${ }^{49}$ Primeri kriminalnega nasilja, ki ga (neposredno ali posredno) zagrešijo psihično normalne osebe, so največkrat vzeti iz vojnih razmer. Toda, dandanes je vojskovanje vse bolj plačana dejavnost profesionalcev, službeno opravilo, ki ga proizvajalcem uničevanja (ljudi in stvari) odrejajo javni in zasebni delodajalci. Zato je omogočanje in udejanjanje - osebnega, še posebej pa strukturnega in institucionalnega - primerneje umestiti v oblastni mehanizem delovne organizacije (ne pa v politično ali pravno razmerje med državo in državljanom). V takem kontekstu sta dobro in slabo tipično (pre)interpretirana glede na kakovost izvedbe nalog (ali projektov), ki jih podrejenemu delavcu nalagajo nadrejeni, in glede na (ne)upoštevanje predpisanih postopkov. Posameznik je znotraj zasebne ali javne oblastne organizacije (ki po obliki vladavine najpogosteje že od daleč spominja na tiranijo) odgovoren zgolj za svoje početje (tehnično usposobljenost in zavzeto mobilizacijo vseh osebnostnih resursov, ki so potrebne za učinkovito, produktivno, lojalno in profesionalno služenje temu ali onemu gospodarju), ne pa tudi za končne cilje in dejanske posledice svojega

vesoljih. Glej Chamayou (2016: 109-117).

48 Takšen ,jagodni izbor“ ni presenetljiv, saj se praviloma znajdejo pod drobnogledom zgolj grozodejstva tistih, ki so v vojni (in navsezadnje tudi v miru) poraženi. Ti so tisti, ki jih čeravno običajno zelo selektivno - doleti pravica, namreč obtožba, obsodba in kazen. In to traja samo tako dolgo, dokler se karte - in hkrati še zgodovinski spomin (ali amnezija) - ne premešajo znova (glej Bauman 2016: 222-225). Po imploziji sovjetskega imperija, zmagi liberalizma $\mathrm{v}$ hladni vojni in kontrarevolucionarni restavraciji kapitalizma $\mathrm{v}$ „tranzicijskih“ postsocialističnih državah je na široko razprtih krilih revizionističnega zgodovinopisja popustil tudi povojni antifašistični konsenz. Po novem se absolutno politično in moralno zlo čedalje bolj istoveti z revolucionarno („totalitaristično“) tradicijo, socializmom in komunizmom. Šteje se, da sta bila fašizem in nacizem zgolj obrambni reakciji na zločinske prakse boljševizma (silobran ali ravnanje v skrajni sili), njuni kvizlinški kolaboranti pa so se iz hudobcev prelevili $\mathrm{v}$ žrtve, ki jim je treba izkazati dolžno spoštovanje. Za natančnejši prikaz revizije zgodovine in vračanja fašizma v kontekstu liberalne demokracije glej Mastnak (2015: 74-85).

49 Za podrobnejše opise tovrstnih - eksperimentalnih in dejanskih - primerov glej Bauman (2013: 100-110). Za natančno analizo „etike poslušnosti“ (in komentar Milgramovih poskusov) glej Bauman (2006: 233-256). 
konkretnega delovnega prispevka, ki je navadno zgolj kamenček v pisanem mozaiku razvejene (in vse pogosteje tudi geografsko razpršene) delitve dela. Počne zgolj to, kar je v dani poklicni vlogi pač treba početi. Recimo: stranki ali nadrejenim pokaže, kako je mogoče elegantno obiti, raztegniti ali preluknjati veljavne predpise. Išče varne metode za izogibanje plačevanju davkov. Lobira za družbeno ali ekološko škodljivo politično odločitev. Podkupuje ali izsiljuje nosilce državne oblasti. Pere umazan denar. Svetuje, kako odpuščati delavce. Nateguje potrošnike z marketinški ali oglaševalskimi triki. Uči kandidate, kako naj manipulirajo z volivci, če hočejo zmagati na volitvah. Lošči zapacano javno podobo korporacij ali strankarskih veljakov. Razvija novo orožje. Izumlja naprave ali programe za čim bolj minuciozno nadzorovanje zaposlenih. Sodeluje v napadu ali okupaciji druge države. Muči in pobija „teroriste“. In tako dalje. A vse to mora navsezadnje početi tudi zato, ker je naravno bitje s potrebami, ki jih je zmore zadovoljevati le, če se mu posreči zaslužiti denar s prodajo svoje delovne sile (,,̌̌e tega ne bi delal jaz, bi se s tem ukvarjal nekdo drug; nič bistvenega se torej ne bi spremenilo: razlika je ta, da sem zdaj jaz tisti, ki prejema plačo, ne pa kdo drug $\left.{ }^{66}\right) .{ }^{50}$

Slišati in videti je, da so duše v postmodernem, globaliziranem kapitalizmu v dokaj klavrnem stanju. Trpijo in zbolevajo, ne počutijo se dobro v svoji nevidni, a raskavi koži, zvijajo se v bolečinah, mučijo jih neprijetna in žalostna čustva, obhajajo jih mračne misli, nenehno jih dražijo nove in nove skušnjave, zaznamovane so z neizbrisnimi travmami, manjka jim samospoštovanje, zasledujejo jih dramatične epizode iz otroštva (npr. premalo ali preveč ljubeča mati in premalo ali preveč strogi oče), razjedajo jih črvi dvoma v smiselnost eksistence, plaši jih razkrajanje trdnih orientacijskih točk, hromi jih negotovost, preplavlja jih strah pred grozečo prihodnostjo (,ک̌̌e hujše bo“) ... Zdi se, da so psihične stiske porazdeljene precej „demokratično“. Nikomur ni a priori prizaneseno. Trpijo bogati in revni (ter kajpak oni vmes, nestrpni milijonarji na čakanju), slavni in brezimni, starci (ki so vsaj z eno nogo že v grobu, a jim čudeži sodobne medicine ustrežljivo podaljšujejo agonijo), otroci, mladostniki in ljudje (obeh spolov) ,v najboljših letih“, uparjeni in samski, zaposleni in brezposelni, normalni in moteni, zdravi in bolni, lepi in grdi ... Mnogi

50 Še neznansko lažje je najti primere zakonitega in nezakonitega kriminalnega (ali družbeno škodljivega) okoriščanja, katerega nepopustljivi protagonisti so psihično zgledno normalni (in še predobro socializirani) posamezniki. Zadostuje, da si zatisnemo nos in se ozremo na prostrana (post)tranzicijska močvirja. V razburkanem obdobju rokohitrsko restavracije kapitalizma so kriminalno prizorišče zavzeli liki, ki se močno razlikujejo od klavrnih junakov nekdanjih črnih kronik, npr. šefi držav, predsedniki vlad, ministri, poslanci, svetniki, župani, sodniki, tožilci, državni funkcionarji in uradniki, policisti, kriminalisti, vojaki, oficirji, člani tajnih služb, svete strankarske krave, direktorji podjetij, člani nadzornih odborov, bančniki, borzniki, finančni čarovniki, cerkveni dostojanstveniki, novinarji, advokati, akademiki, zdravniki, kulturniki, umetniki, voditelji humanitarnih ali nevladnih organizacij ... Vidimo torej, da ta nov zarod kriminalnih udarnikov, vsaj večinoma, ne označuje le odsotnost psihične motenosti, marveč tudi drugih primanjkljajev, ki so se tradicionalno dojemali kot ključni dejavniki kriminalnega vedenja, npr. revščina, brezposelnost, neizobraženost, odraščanje v disfunkcionalni družini, luknjičava samokontrola, nizek IQ, marginalen ali diskriminiran položaj v družbi in tako dalje. Novi kriminalci se razlikujejo od svojih starih (,,konvencionalnih“) kolegov predvsem v tem, da so v svojih tatinskih in prevarantskih podvigih neprimerno bolj uspešni in da so le sporadično deležni resne kazenske sankcije. 
svoje duševne probleme skrbno skrivajo, kajti nesrečnost se v dominantni kulturi interpretira kot ultimativno znamenje eksistencialnega brodoloma, kot sramoten (trajni ali začasni) poraz, za katerega je kriv primarno posameznik kot tak, npr. zato, ker se ni dovolj (po)trudil, ker ni izkoristil priložnosti, ki jih je imel (ali jih ima) na voljo, ker je sprejemal napačne odločitve, ker se je požvižgal na nasvete in priporočila strokovnjakov za srečno, uspešno in zdravo življenje (ali za razvijanje čustvene inteligence, pospešeno osebnostno rast, spopadanje s stresom, osamljenostjo, krizo srednjih let, ovelimi seksualnimi praksami v monogamni partnerskem razmerju, utrujenostjo, tesnobo in drugimi ,sodobnimi tegobami“"), ker ni dovolj konkurenčen ali podjeten, ker skrivoma (iz nezavednih motivov) uživa v svojem trpljenju, okrnjenem jazu ali patološkem ravnanju, ker ... Mnogi pa svoje križe in težave rade volje in brez kančka sramu razkrivajo pred javnostjo, npr. $\mathrm{v}$ televizijskih in radijskih pogovornih oddajah, intervjujih ali kibernetskem vesolju. Zvedavega občinstva, ki jim je voljno pozorno prisluhniti, ne (z)manjka. Zanimivo pa je, da se individualne stiske, čeprav imajo pogosto podobne vzroke (zlasti v strukturah kapitalističnega gospodarstva in institucionalnega patriarhata) dandanes ne seštevajo več v ,skupno stvar“, ki bi ljudi usmerila v skupno in organizirano politično delovanje. Pričakuje se namreč (in celo zaželeno je), da jih (in se) rešuje vsak sam, kot pač najbolje ve in more.

$\mathrm{V}$ tem, da ljudje trpijo, ni nič pretresljivo novega (morda je, vsaj na prvi in naivni pogled, presenetljivo zgolj to, da je ogromno duševnih stisk zgoščeno ravno $\mathrm{v}$ družbah, ki se ponašajo z zgodovinsko neprimerljivo ravnijo materialne blaginje, v gospodarsko razvitih okoljih, kjer se posamezniku na trgu ponujajo čedalje bolj izpopolnjeni pripomočki, ki naj bi mu ,prihranili čas“, olajšali naporna opravila, odganjali dolgčas, ga spravljali v dobro voljo, zabavali, informirali, izobraževali, vključevali v družabna omrežja, povečevali telesne in mentalne zmogljivosti in omogočali izražati njegovo edinstveno osebnost ali avtentični jaz). Že človeško življenje kot tako - torej ne oziraje se na raznovrstno zlo, ${ }^{51}$ ki izvira iz medosebnih razmerij, represivnih družbenih struktur, kulturnih omejitev, oblastnih razmerij in naravnih nesreč - je namreč nerazvezljivo povezano s takim in drugačnim trpljenjem. ${ }^{52}$

51 Za zgoščen prikaz družbeno povzročenega zla glej Rousseau (1993: 87-93).

52 Freud (1977: 22) trpko priznava, da je življenje, kakršno nam je naloženo, za nas pretežko, saj nam prinaša preveč nelagodja, bolečin, razočaranj, nesreč in nerešljivih nalog. Schopenhauer (2008: 329-345) poudarja, da je trpljenje bistvena sestavina življenja, saj ne prihaja samo od zunaj, ampak ima svoj neizčrpen vir že v posameznikovi notranjosti. Človek je namreč bitje neusahljivega stremljenja, ki izvira iz pomanjkanja ali nezadovoljstva z danim stanjem. Ko si želi, da bi dosegel to ali ono dobrino, trpi. Ko je želja izpolnjena, je zadovoljen, a ne za dolgo. Pojavijo se nove želje ali pa dolgočasje, ki ni nič manj mučno kakor nenehno prizadevanje za golo samoohranitev. Schopenhauer (2008: 341) pesimistično ocenjuje, da je človekov položaj tako zelo (in neodpravljivo) beden, da bi nam moralo biti ljubše ne biti kakor biti: „Resnično neverjetno je, kako prazno in brez vsakršnega pomena, gledano od zunaj, in kako topo in nezavedno, občuteno od znotraj, mineva življenje velike večine ljudi. Je medlo hrepenenje in mučenje, sanjavo opotekanje skozi štiri življenjske dobe proti smrti v spremstvu trivialnih misli. Ljudje so podobni uram, ki se jih navije in zatem tečejo, ne da bi vedele zakaj, in vsakič, ko se spočne in rodi človek, se znova navije ura človekovega življenja, da bi znova ponovila že ničkolikokrat odigrano skladbo, stavek za stavkom, takt za taktom in z nepomembnimi variacijami.“ No, mnogi so prepričani, da le ni vse tako črno in da je mogoče trpljenje korenito 
Preprosto rečeno: človeški subjekt trpi že zgolj zato, ker je živ (ker še ni mrtev ali ker se mu ni posrečilo, da ne bi bil rojen), ker je ujet v življenje, v organizem, ki trmasto teži k samoohranitvi in ga sili zdaj v to, zdaj v ono naprezanje, ki pa se za nameček ne izteče vedno tako, kot bi si (ali si je) želel. No, to je že zelo stara, prastara zgodba, tako kot tudi trnovo vprašanje, kako odpraviti ali vsaj korenito skrčiti psihično bedo, ki nepopustljivo pritiska na človeška bitja. S tem nadležnim problemom so si v preteklosti razbijali glave preroki, modreci, učenjaki, sofisti, filozofi, duhovniki in umetniki. V današnjem času pa ga rešujejo predvsem znanstveniki, zdravniki, psihiatri, psihologi, psihoterapevti, svetovalci, socialni delavci, proizvajalci (in prodajalci) psihotropnih snovi, tržniki in oglaševalci. Treba je priznati, da se še nikoli doslej ni tolikšna armada najrazličnejših strokovnjakov ukvarjala z vprašanjem, kaj dejansko (subjektivno in „objektivno“) je človeška srečnost, kaj jo omogoča ali povzroča, kako nastane in kateri so njeni smrtni sovražniki.

V vojno zoper psihične motnje, trpljenje in nesrečnost pa so vpleteni tudi v oči bijoči materialni in poslovni interesi. Očitno je namreč, da je povpraševanje po izdelkih in storitvah, ki obljubljajo izhod iz duševne bede, precej obsežno, krepi in ustvarja pa ga tudi razvejena ponudba. V tej luči vsekakor ni presenetljivo: (a) da je ideal duševnega zdravja (npr. „samouresničitev“) v terapevtskem diskurzu pogosto postavljen tako visoko (ali opredeljen tako megleno), da je tako rekoč vsak običajen smrtnik po takem merilu videti „bolan“, „nevrotičen“, „,neprilagojen“ ali „disfunkcionalen“ (in torej potreben strokovne pomoči, ki bo - v zameno za ustrezno plačilo - predelala njegov poškodovani jaz); ${ }^{53}$ (b) da se čedalje več neprijetnih življenjskih izkušenj (in z njimi spetih vedenjskih vzorcev) dojema in obravnava kot bolezenske (,psihiatrične“) motnje ${ }^{54}$ (c) da se duševni problemi vse pogosteje rešujejo z jemanjem zdravil (npr.

zmanjšati ali celo prevesiti tehtnico v prid ugodja ali užitka (ki pa, kot vemo, ni vselej prijeten). Znano je, da človek - bitje, je rezultat slepih in brezciljnih evolucijskih procesov - dosti lažje prenaša tegobe, če ima ali verjame $\mathrm{v}$ nekaj, zaradi česar se mu zdi vredno truditi, mučiti in vztrajati, in torej v svojem življenju najde neki „smisel“ (Frankl 2013: 129-131), še bolje pa je, če se njegova subjektivna iluzija ujema s prevladujočimi kulturnimi utvarami, namišljenimi realnostmi, v katere verjamejo tudi drugi. Zahtevnejšo rešitev predlaga budizem, ki poudarja, da resnična sreča ni odvisna niti od zunanjih okoliščin niti od naših notranjih občutkov. Zato se ne kaže pehati niti za zunanjimi dosežki niti za prijetnimi občutji. Stanje popolnega zadovoljstva in spokojnosti vznikne šele tedaj, ko so plameni želja dokončno pogašeni in ko se stvarnost dojema brez sanjarjenj ali slepil (Harari 2015: 398-402). Trpljenje izgine le, če si ničesar ne želimo. Za sodobna pojmovanja srečnosti in nesrečnosti glej Bruckner (2004: 55-69).

53 Za kritično osvetlitev glavnih značilnosti prevladujočega terapevtskega diskurza glej Illouz (2010: 58-79).

54 Petrovec (2015: 20) opozarja, da je psihiatrični priročnik iz leta 1952 vseboval 106 diagnoz, v peti izdaji iz leta 2013 pa jih je že 312: „Teh dvesto novih psihiatričnih motenj seveda niso 'odkrili', ampak so dogovorjene.“ Tudi Illouz (2010: 78) poudarja, da je čedalje več obnašanj interpretiranih kot pokazatelj bolezenske motnje. Recimo: posameznik, ki je neubogljiv, negativističen ali izzivalen do predstavnikov oblasti ima „motnjo nasprotovanja“; posameznik, ki je živahen, dramatičen in nenehno priteguje pozornost nase, trpi za „motnjo teatralne osebnosti“; posameznik, ki je pretirano občutljiv na potencialno zavrnitev, ponižanje ali sram in nepripravljen vstopiti v odnos brez nenavadno močnih jamstev za nekritični sprejem, ima „motnjo izogibajoče se osebnosti“. Galimberti (2011: 141-145) se sprašuje, v čem je smisel jezikovnih premen, ki še pred kratkim običajne življenjske pojave - npr. živahnost 
pomirjeval, uspaval in antidepresivov) ali uživanjem dovoljenih in prepovedanih drog. Razlogi za mikavnost, priljubljenost in množično uporabo medicinsko predpisanih, komercialnih (tržno dostopnih) in prepovedanih psihotropnih substanc (ne glede na negativne stranske učinke in možnost zdrsa v odvisnost) niso nikakršna skrivnost. ${ }^{55} \mathrm{Te}$ reči delujejo dokaj hitro, zanesljivo in predvidljivo. Recimo: (a) pomirjajo in zazibljejo v spanec; (b) izostrijo pozornost in podaljšajo budnost; (c) olajšajo in spodbujajo komunikacijo; (č) povečujejo delavčevo storilnost, produktivnost ali kreativnost in eo ipso konkurenčnost; (d) pričarajo užitek, dobro počutje ali občutek povečane moči (in morda celo privid narcistične vsemogočnosti); (e) odganjajo dušeče ali moreče skrbi, tesnobo, strah, žalost, potrtost in druge nevšečne ali nezaželene emocije; (f) razrahljajo ali nevtralizirajo nadležne pritiske nevzdržne realnosti, družbenih vlog ali karakternih mask; (g) ustvarjajo zavetje, v katerem so pogoji občutenja notranjega in zunanjega sveta znosnejši; (h) posameznika naredijo neobčutljivega za življenje, v katerem ne najde več niti smisla niti upanja na boljšo prihodnost, pravzaprav ničesar, kar bi mu bilo v pomoč pri soočanju z mučno dolgočasnostjo, plehkostjo, banalnostjo, enoličnostjo njegove (pogosto osamljene) eksistence. Po drugi strani pa je odnos družbe do „čudežnih“ substanc (naravnih in umetnih pripomočkov za ,goljufivo“ upravljanje duševnih stanj) že dolgo „shizofren“: zoper nekatere snovi (,droge“ ali „mamila“) vodi pravcato križarsko vojno (ki močno obremenjuje kazenskopravni sistem in polni zapore z uživalci, odvisniki, preprodajalci in proizvajalci ,prepovedanih sadežev"), medtem ko so druge, zlasti tiste, ki se opirajo na medinski ali psihiatrični alibi in ki jih na trg pošiljajo ugledna farmacevtska podjetja, toplo priporočene (čedalje bolj tudi za obvladovanje otroških duševnih stisk in vedenjskih motenj). Kakorkoli že, če drži, da ,je biokemija človeškega bitja zelo občutljiva na družbene okoliščine“ (Ronald Laing), potem velja tudi ocena, da je normalno družbeno in ekonomsko življenje zelo (morda celo čedalje bolj) odvisno od biokemije. ${ }^{56}$

in nemirnost (,hiperaktivnost in motnja pozornosti“), plahost („družabna anksioznost“), zadržanost (,družabna fobija“) in zaskrbljenost (,,splošna anksioznost“) - zdaj predstavljajo kot psihopatološke sindrome. Po njegovem mnenju je v ozadju težnja nadzorstvenih mehanizmov, da vzpostavijo „gospostvo nad dušami“: da se posamezniki čustveno poenotijo (ali izenačijo) in prilagodijo konformističnemu življenjskemu slogu, usklajenemu z zahtevami kapitalistične družbene dejanskosti. .

55 Zgolj za ilustracijo: Petrovec (2015: 20) ugotavlja, da so leta 1986 v ZDA prodali za 500 milijonov dolarjev antidepresivov in antipsihotikov, leta 2004 pa že za 20 milijard. Galimberti (2011: 192-193) ocenjuje, da je bilo leta $2001 \mathrm{v}$ Italiji - kjer naj bi bilo približno 10 milijonov duševno motenih (s katerimi delijo trpljenje tudi številne družine) in kjer si je vsak dan vzelo življenje deset obupancev (desetim pa se to ni posrečilo) - 2 milijona uporabnikov pomirjeval, 3 milijone uporabnikov anksiolitikov in 5 milijonov uporabnikov antidepresivov. Ryan in Jethà (2013: 291) opozarjata, da so najpogosteje predpisna zdravila v ZDA antidepresivi (leta 2005 je bilo izdanih kar 118 milijonov receptov), katerih stranski učinek je tudi zmanjšanje spolnega poželenja, kar pa sanira viagra, prodajna uspešnica, ki poskrbi za boljšo prekrvavitev in omogoča moškemu vsaj hlinjeno strast. Galeano (2011. 198) poudarja, da porabijo ZDA polovico vseh pomirjeval, antidepresivov in drugih sintetičnih drog, ki se prodajajo zakonito, in več kot polovico prepovedanih drog, kar ni mačji kašelj, če upoštevamo, da živi tamkaj le 5 odstotkov svetovnega prebivalstva. Berardi (2013: 170) navaja podatek, da jemlje antidepresive 24 milijonov Angležev (sledi prozaca so zaznali že celo v vodi, ki teče iz londonskih pip).

56 Berardi (2013: 110-113) povezuje „psihofarmakološko eksplozijo“ v devetdesetih letih 
Podatki o številu ljudi, ki trpijo zaradi takšnih in drugačnih duševnih težav ali motenj (in ki storijo samomor, ker so se njihovi upi posušili ali izhlapeli na vročem pesku emocionalne puščave), se pogosto uporabijo kot argument, ki upravičuje kritiko obstoječe družbe in kulture (,samo poglejte, koliko je nesrečnežev, ki jih sistem poškoduje ali dokončno zmelje v prah" $).{ }^{57} \mathrm{~A}$ kapitalistični perpetuum mobile se za tovrstne očitke ne zmeni. Mudi se mu naprej, novim zmagam naproti. Pomemben dejavnik, ki pojasnjuje osupljivo trdoživost tega zgodovinskega produkcijskega načina, je ideologija kot „religija vsakdanjega življenja“, ki je za Marxa (1973: 925) poglavitna duševna motnja ljudi v meščanski družbi, zaradi katere se jim svet prikazuje $\mathrm{v}$,začarani in na glavo postavljeni“ podobi, v obliki kapitalskih, denarnih in blagovnih fetišev ter mistifikacij (sprevrnitev dejanskih razmerij). Podčrtati velja, da ideološke predstave niso subjektivne, marveč objektivne, družbeno veljavne iluzije. Niso preprosto „napačna zavest“ niti plod načrtne (ali zahrbtne) manipulacije, propagande ali indoktrinacije. Posameznik jih privzame scela spontano in nezavedno, že zgolj z normalno in dejavno vključitvijo v kapitalistična družbenoekonomska razmerja, in sicer ne glede na funkcijo, ki jo opravlja, in položaj v razredni hierarhiji. V izkrivljeni ideološki perspektivi so kapital, zemlja in delovna sila videti kot „faktorji“ ustvarjene vrednosti, ne pa zgolj kot viri, ki njihovih lastnikom omogočajo zakonito prisvajanje dohodka, namreč profita (podjetnikovega dobička in obresti), rente in

prejšnjega stoletja - namreč množično uporabo zdravil z evforičnim učinkom in substanc, ki omogočajo „nevroprogramiranje“ in mobilizacijo psihične energije $-\mathrm{z}$ imperativi visokotehnološke kapitalistične ekonomije, ki od posameznikov zahteva izredno visoke ravni konkurenčnosti, agresivnosti in učinkovitosti, in to v kontekstu bolj ali manj nepretrganega „elektrošoka“, hiperstimulacije živčnega sistema, zasičene pozornosti, psihičnega (percepcijskega in kognitivnega) stresa, pospeševanja ritmov globalnega produkcijskega stroja, ekspanzije kibernetskega prostora in bohotenja informacij, ki jih um ne zmore več prebaviti. Po njegovem mnenju so dovoljene droge (ki prinašajo fantastične dobičke mogočnim farmacevtskim korporacijam) in prepovedane droge (ki polnijo žepe organiziranega kriminala mafijske sorte) postale bistven (ali morda že celo najpomembnejši) dejavnik hiperkompetitivne družbe. Berardi (2013: 114) poudarja, da se psihopatologija rojeva prav tam, kjer propagandisti ekonomske konkurenčnosti vidijo rajske rezervoarje vsakovrstnih priložnosti: „Že zgolj beseda priložnost je psihopatološka, obenem pa še iluzorna. Vsakič, ko kak apologet ekonomije uporabi besedo 'priložnost', morate biti pozorni: to pomeni, da se želi nekdo obogatiti z vašim delom.“

57 Galimberti (2011: 193) opozarja na oceno Svetovne zdravstvene organizacije, po kateri trpi na tem prenatrpanem planetu zaradi duševnih motenj milijarda ljudi (šestina človeštva), od katerih jih 600 milijonov prebiva v gospodarsko razvitih državah, kjer ,so ljudje vedno manj osebe z lastnim življenjem in vedno bolj 'nameščenci' aparatov, ki jih zaposlujejo in jim določajo življenjske pogoje." Italijanski filozof poudarja, da osrednja bolezen postmodernega zahodnega sveta ni več nevroza (ki temelji na konfliktu med željo, ki hoče prelomiti pravilo, in pravilom, ki hoče zadržati željo), marveč depresija, katere jedro se razvije iz občutka posameznikove nezadostnosti in neustreznosti glede tisto, kar bi bilo mogoče storiti, vendar pa tega ni bil zmožen uresničiti. Depresija (stanje brezvoljnosti in zavrtosti, v katerem ti zunanji svet ne pove ničesar več, načrti za prihodnost pa so oviti v grobno tišino) torej ne izrašča iz konflikta med dovoljenim in prepovedanim (ki je bil najbolj razširjen v modernih disciplinskih družbah), ampak iz precej silovitejšega nasprotja med mogočim in nemogočim. Za bolj poglobljeno analizo postmoderne depresivnosti glej Galimberti (2010: 69-74). Za pregled staro- in srednjeveških pojmovanj in zdravljenj melanholije glej Burton (2012: 21-105). 
mezde. Zato se zdi, da lastniki kapitala, zemlje in delovne sile prejmejo dohodke, ki ustrezajo tistemu delu vrednosti produkta, ki ga je ustvaril ali „dodal“ njihov „produkcijski faktor“. Mezda, denimo, se ne prikazuje kot denarni ekvivalent kupljene delovne sile, marveč kot plačilo za konkretni delovni prispevek, s čimer se zamegli obstoj presežnega dela, izkoriščanja (zasebnega prisvajanja presežne vrednosti) in razrednega gospostva: vsakdo dobi (vsaj približno) to, kar mu pripada. Profit - edini smoter kapitalističnega gospodarjenja in glavni usmerjevalec odločitev o tem, kaj (in koliko) proizvajati in $\mathrm{v}$ kaj investirati - je videti kot dosežek posamičnega podjetja $\mathrm{v}$ tržni tekmi s konkurenti (ne pa kot rezultat delovanja celotnega sistema, denarni zastopnik presežnega dela ali tisto, kar ostane, ko prodaja blaga omogoči obnovitev ali nadomestitev porabljenih surovin, orodja, stroja in delovne sile). Če mezda ustreza vrednostnemu prispevku opravljenega dela, potem se zdi, da izvirajo profiti iz produktivnosti kapitala ali aktivnosti podjetnikov, katerih specifične sposobnosti navsezadnje upravičujejo njihove visoke dohodke. To, da podjetja $\mathrm{z}$ avtomatizirano ali robotsko produkcijo poslujejo dobičkonosno, ustvarja vtis, da eksploatacija ne obstaja ${ }^{58}$ Gospodarska kriza, ki jo označuje presežek (in ne pomanjkanje) dobrin (ki jih ni mogoče donosno prodati), se prikazuje kot posledica skrivnostnih eksogenih dejavnikov (ne pa padajoče profitne stopnje). Kapitalizem se kaže zgolj kot „tržno gospodarstvo“, v katerem si zasebna podjetja prizadevajo kar najbolje in najceneje zadovoljevati preference suverenih potrošnikov (in celo kot sistem, ki naj bi že po svoji naravi težil k stabilnemu ravnovesju). ${ }^{59}$

Ideologija seveda ni sinonim za zaslepitev. Posameznik, čigar moteno zaznavanje in razmišljanje formatirajo ideološke predstave (za „hrbtom“ njegove zavesti), lahko še vedno jasno in razločno opaža iracionalnost, destruktivnost in krivičnost kapitalističnega gospodarstva (in meščanske družbe), npr. groteskno nabrekanje neenakosti $\mathrm{v}$ dohodkih in gmotnem bogastvu, ${ }^{60}$ sistematično uničevanje in zastrupljanje nečloveške narave, povečevanje odvečne populacije (ki, če ima srečo,

58 Karatani (2010: 302-303) opozarja, da je nesorazmerje med doseženo stopnjo profita in količino vloženega dela posledica prerazdelitve presežne vrednosti, ki jo izčrpajo drugi kapitali: „Predpostavka, da prihaja do izkoriščanja zgolj v produkcijskem procesu posameznih kapitalov, ni le zgrešena, temveč je celo škodljiva. [...] Profit določenega individualnega kapitala je udeležen na presežni vrednosti kapitalov drugih industrijskih panog in samostojnih malih podjetnikov, profit celotnega kapitala države pa je udeležen na presežni vrednosti, ki nastaja v tujini (v kolonijah). Težava je v tem, da so ti detajli vselej nevidni in netransparentni.“

59 Za podrobnejšo analizo učinkovanja kapitalistične ideologije glej Marx (1973: 907-926); Heinrich (2013. 195-202); Lebowitz (2014: 24-29); Mattick (2013: 55-59).

60 Oxfam (2016: 7-9) poroča, da dosegajo družbenoekonomske neenakosti nove skrajnosti, saj ima najbogatejši en odstotek zemljanov dandanes že več premoženja kakor ves preostali svet skupaj. Moč denarja in z njo zlepljeni privilegiji bogatašem omogočajo, da si prirejajo gospodarski sistem tako, da se razlike med njimi in vsemi drugimi še povečujejo. Za nameček pa jim razvejeni arhipelag davčnih oaz omogoča, da v tem vzporednem svetu (tostranskem raju za bogataše) skrivajo približno 7,6 bilijona ameriških dolarjev. Oxfamovi izračuni so pokazali, da je imelo leta 2015 zgolj 62 posameznikov (v letu 2010 še 388) v lasti enako količino premoženja kakor 3,6 milijarde ljudi, tj. spodnja polovica človeštva. Premoženje najbogatejših 62 posameznikov se je obdobju 2010-2015 povečalo za 44 odstotkov (za 542 milijard dolarjev), medtem ko se je premoženje spodnje polovice zmanjšalo za 41 odstotkov (za nekaj čez bilijon dolarjev). 
najde kruh le še v neformalni ali črni ekonomiji), ${ }^{61}$ upniško ugrabljanje in odiranje nacionalnih držav, zločinske vojaške intervencije imperialističnih sil, neznosne delovne obremenitve, bizarno ekspanzijo povsem nesmiselnih služb, ponižujoče oblike nadzora nad zaposlenimi, škodljivost konkurence, aroganco vsemogočnih šefov, organizirano izmikanje plačevanju davkov, ${ }^{62}$ izsiljevalske in plenilske poslovne prakse globalnih korporacij in tako dalje. No, marsikaj od tega ljudje dejansko vidijo. A njihova nezadovoljstva, jeza, zamere in druga reaktivna čustva se v glavnem ne usmerjajo proti dominantnemu sistemu, marveč se obešajo na tega ali onega grešnega kozla (npr. na nezaželene priseljence, nepriljubljeno vlado, nesposobno in zapravljivo državno birokracijo, skorumpirane politične elite ali pogoltne finančnike, ki pijejo kri „realnemu“ ali „produktivnemu“ gospodarstvu) ali na zahteve po boljši ekonomski politiki, višjih plačah, kapitalizmu s človeškim ali socialnim obrazom ... Toda pozor. Kaj bi se zgodilo, če bi se vsaj „kritični masi“ podrejenih posrečil intelektualni preboj skozi goste ideološke meglice? Bi se iz ,pravilnega“ spoznanja dejanskih družbenih razmerij porodila revolucionarna razredna zavest? Ne nujno in morda celo malo verjetno, sploh če upoštevamo, da so prodajalci delovne sile priklenjeni na potrošniški kapitalizem predvsem čustveno, namreč s svojimi željami in aspiracijami. Nikjer ne piše, da ljudje komaj čakajo „odrešitev“ v socialistični, komunistični ali anarhistični družbeni formacijami (ali da bi bili v brezrazrednem sistemu, utemeljenem na „svobodi, solidarnosti in enakosti“, srečnejši)? Kaj če postmoderne subjekte zanimajo le še individualni projekti (ali zasebne utopije), npr. poklicna, poslovna in finančna uspešnost, samouresničevanje (v službi, družinski celici in nakupovalnem središču), zdrav življenjski slog, medijski trash ali bebava zabava? Kaj če jih zadovoljuje že zgolj opazovanje realnega ali simuliranega uživanja drugih, npr. lepih, zmagovitih, premožnih, slavnih in znanih likov? Kaj če za njihovo srečo (ali vsaj znosno počutje) zadostujejo dober avto, ${ }^{63}$ hitre ceste, prostrana in varna parkirišča, zrenje v sijoče ekrane čedalje „pametnejših“ informacijskih in komunikacijskih aparatov, Facebook, Twitter, Instagram, računalniške igrice, reality shows, limonadaste nadaljevanke, kvizi, igre na srečo, medijski trači, nori popusti in komercialno blago $\mathrm{v}$ akciji, izlivanje gneva na kibernetska smetišča, opiranje na identitetne bergle šovinizma,

61 Davis (2009: 255-257) ugotavlja, da je bila konec devetdesetih let pod- ali nezaposlena milijarda delavcev, tretjina svetovne delovne sile. Presežno človeštvo se skladišči predvsem v barakarskih naseljih (,slumih“), kjer prebivalstvo narašča za neverjetnih 25 milijonov na leto.

62 Obstoj davčnih oaz, temeljnega kolesja finančnega kapitalizma, ni več nikakršna skrivnost. Uporabljajo jih bogataši in mogočneži z vsega sveta. Zucman (2016: 7) ugotavlja, da utaja davkov, ki jo omogoča bančna tajnost, še vedno odlično uspeva. Na svetovni ravni se v davčnih oazah skrivoma hrani 8 odstotkov finančnega premoženja, kar je zgodovinski rekord, v EU pa je delež še višji, saj se približuje 12 odstotkom (Francozi, denimo imajo offshore skoraj 350 milijard evrov, od tega polovico v Švici, ki je še vedno najpomembnejši svetovni center za upravljanje in prikrivanje premoženja).

63 Wilson in Zarate (2002: 99) opozarjata, da je bil avtomobil, ki ga poganja bencinski motor, sprva oglaševan kot terapevtski pripomoček. V številki revije British Medical Journal, v kateri je Freud prvič predstavil svoje ideje britanski strokovni javnosti, je bil objavljen tudi uvodnik z naslovom „Terapevtske zmožnosti avtomobilizma“, v katerem je avtor poročal o dobrodejnih učinkih ,primerno dozirane vožnje z avtomobilom“ na posameznike, ki trpijo zaradi anemičnosti, nevrastenije, nespečnosti, ki je živčnega izvora, in atonične dispepsije. 
narodnjaštva, seksizma, rasizma, verskega fundamentalizma ali (izumljenega ali oživljenega) tradicionalizma in učinek te ali one psihotropne substance? No, nikakor pa ne kaže izključiti možnosti, da so konformistično večino vendarle prepričale klene besede železne baronice Margaret Thatcher, da alternative kapitalizmu preprosto ni več. Izpuhtela je v zrak. Duše imajo potemtakem pred seboj le še eno pravo pot. Srečno!

\section{LITERATURA}

1. Adorno, T. W. (2007). Minima moralia: refleksije iz poškodovanega življenja. Ljubljana, Založba /*cf.

2. Arendt, H. (2006). Med preteklostjo in prihodnostjo: šest vaj v političnem mišljenju. Ljubljana, Krtina.

3. Avguštin, A. (2003). Izpovedi. Celje, Mohorjeva družba.

4. Bauer, J. (2008). Princip človeškosti. Ljubljana, Študentska založba.

5. Bauman, Z. (2016). Postmoderna etika. Ljubljana, Znanstvena založba Filozofske fakultete.

6. Bauman, Z. (2013). Kolateralna škoda. Ljubljana, Znanstvena založba Filozofske fakultete Univerze v Ljubljani.

7. Bauman, Z. (2006). Moderna in holokavst. Ljubljana, Študentska založba.

8. Beauvois, J-L. (2000). Razprava o liberalni sužnosti: analiza podrejanja. Ljubljana, Krtina.

9. Beccaria, C. (2002). O zločinih in kaznih. Ljubljana, Pravna fakulteta in Cankarjeva založba.

10. Bembič, B. (2012). Kapitalizem v prehodih: politična in ekonomska zgodovina Zahoda po drugi svetovni vojni. Ljubljana, Sophia.

11. Berardi, F. (2013). Duša na delu. Ljubljana, Maska.

12. Bock, G. (2004). Ženske v evropski zgodovini. Ljubljana, Založba /*cf.

13. Bruckner, P. (2004). Nenehna vzhičenost: esej o prisilni sreči. Ljubljana, Študentska založba.

14. Bunta, A. (2015). Ime česa je nevroznanost? V: R. Salecl et. al., Možgani na zatožni klopi. Ljubljana, Inštitut za kriminologijo in GV Založba, str. 11-32.

15. Burcar, L. (2015). Restavracija kapitalizma: repatriarhalizacija družbe. Ljubljana, Sophia.

16. Burton, R. (2012). Anatomija melanholije. Ljubljana, Studia humanitats.

17. Chamayou, G. (2016). Teorija drona. Ljubljana, Krtina.

18. Cohen, D. (2011). Tri predavanja o postindustrijski družbi. Ljubljana, Sophia.

19. Damasio, A. (2008). Iskanje Spinoze: veselje, žalost in čuteči možgani. Ljubljana, Krtina.

20. Davis, M. (2009). Planet slumov. Ljubljana, Založba /*cf.

21. Dolenc, S. (2015). Časovna zanka svobodne volje. V: R. Salecl et. al., Možgani na zatožni klopi. Ljubljana, Inštitut za kriminologijo in GV Založba, str. 33-54.

22. Durkheim, E. (2006). Suicide. London, Routledge.

23. Elias, N. (2000). O procesu civiliziranja (Prvi zvezek). Ljubljana, Založba /*cf.

24. Evripid (2000). Medeja; Ifigenija pri Tavrijcih. Ljubljana, Mladinska knjiga.

25. Fischbach, F. (2012). Brez predmeta. Kapitalizem, subjektivnost, odtujitev. Ljubljana, Krtina.

26. Foucault, M. (1984). Nadzorovanje in kaznovanje. Ljubljana, Delavska enotnost.

27. Frankl, V. E. (2013). Kljub vsemu reči življenju da. Celje, Celjska Mohorjeva družba.

28. Freud, S. (1977). Predavanja za uvod v psihoanalizo. Ljubljana, DZS.

29. Galeano, E. (2011). Narobe: šola narobe sveta. Ljubljana, Sanje. 
30. Galimberti, U. (2010). Grozljivi gost: nihilizem in mladi. Ljubljana, Modrijan.

31. Galimberti, U. (2011). Miti našega časa. Ljubljana, Modrijan.

32. Graeber, D. (2014). Dolg: prvih 5000 let dolžništva. Ljubljana, Založba /*cf.

33. Graeber, D. (2013). Fragmenti anarhistične antropologije. Ljubljana, Založba/*cf.

34. Hafner, M. (2015). Nevroznanost v kazenskih postopkih. V: Renata Salecl et. al., Možgani na zatožni klopi. Ljubljana, Inštitut za kriminologijo in GV Založba, str. 89106.

35. Hamilton, C. (2007). Fetiš rasti. Ljubljana, Krtina.

36. Harari, Y. N. (2015). Sapiens: kratka zgodovina človeštva. Ljubljana, Mladinska knjiga.

37. Harvey, D. (2012). Kratka zgodovina neoliberalizma. Ljubljana, Studia humanitatis.

38. Hegel, G. W. F. (2013). Filozofija pravice. Ljubljana, Krtina.

39. Heinrich, M. (2013). Kritika politične ekonomije. Uvod. Ljubljana, Sophia.

40. Hirschman, A. O. (2002). Strasti in interesi: politični argumenti za kapitalizem pred njegovim zmagoslavjem. Ljubljana, Krtina.

41. Hume, D. (2000). Dialogi o naravni religiji. Ljubljana, Društvo za teoretsko psihoanalizo.

42. Illouz, E. (2010). Hladne intimnosti: oblikovanje čustvenega kapitalizma. Ljubljana, Krtina.

43. Jacoby, R. (1981). Družbena amnezija: kritika sodobne psihologije od Adlerja do Lainga. Ljubljana, Cankarjeva založba.

44. Jager, M. (2006). O predpostavki človekove svobodne volje v kazenskem pravu in kriminologiji. Revija za kriminalistiko in kriminologijo, št. 2, str. 143-153.

45. Karantani, K. (2010). Transkritika: o Kantu in Marxu. Ljubljana, Krtina.

46. Koch, M. (2013). Lenoba. Študentska založba, Ljubljana.

47. Kundera, M. (2008). Zastor: esej v sedmih delih. Ljubljana, Modrijan.

48. Kurz, R. (2000). Svet kot volja in dizajn. Ljubljana, Krtina.

49. Lafargue, P. (1972). Le droit à la paresse. François Maspero, Paris.

50. Lebowitz, M. A. (2014). Socialistična alternativa: resnični človekov razvoj. Sophia, Ljubljana.

51. Lordon, , F. (2010). Capitalisme, désir et servitude. Paris, La Fabrique éditions.

52. Marx, K. (1973). Kapital (Tretji zvezek). Ljubljana, Cankarjeva založba.

53. Mastnak, T. (2015). Liberalizem, fašizem, neoliberalizem. Ljubljana, Založba /*cf.

54. Mattick, P. (2013). Vse po starem: gospodarska kriza in polom kapitalizma. Ljubljana, Studia humanitats.

55. Mirandola, G. P. della (1997). O človeškem dostojanstvu. Ljubljana, Družina.

56. Nietzsche, F. (2005). Človeško, prečloveško. Ljubljana, Slovenska matica.

57. Oxfamovo poročilo št. 210 (2016). Gospodarstvo za $1 \%$. Ljubljana, Založba /*cf.

58. Pašukanis, E. (2014). Splošna teorija prava in marksizem. Ljubljana, Sophia.

59. Petrovec, D. (2015). Nasilje pod masko. Ljubljana, Sanje.

60. Rifkin, J. (2007). Konec dela: zaton svetovne delavske sile in nastop posttržne dobe. Ljubljana, Krtina.

61. Rousseau, J. J. (1993). Razprava o izvoru in temeljih neenakosti med ljudmi. Ljubljana, Študentska organizacija Univerze v Ljubljani.

62. Ryan, C.; Jethà, C. (2013). Seks ob zori: predzgodovinski izvori moderne seksualnosti. Ljubljana, Modrijan.

63. Schopenhauer, A. (2008). Svet kot volja in predstava. Ljubljana, Slovenska matica.

64. Singer, P. (2008). Praktična etika. Ljubljana, Krtina.

65. Sloterdijk, P. (2009). Srd in čas. Ljubljana, Študentska založba.,

66. Spinoza, B. de (1988). Etika. Ljubljana, Slovenska matica.

67. Supiot, A. (2013). Duh Filadelfije: socialna pravičnost proti totalnemu trgu. Ljubljana, Založba $/ *$ cf.

68. Todorov, T. (2014). Osvojitev Amerike: vprašanje drugega. Ljubljana, Studia humanitatis. 
69. Virno, P. (2007). Družbene vede in „,̌loveška narava“. Govorna sposobnost, biološka stalnica in proizvodni odnosi. V: M. Foucault, N. Chomsky in P. Virno, Človeška narava in zgodovina. Ljubljana, Krtina, str. 63-165.

70. Vodovnik, Ž. (2010). Anarhija vsakdanjega življenja: zapiski o anarhizmu in njegovih pozabljenih prerokih. Ljubljana, Sophia.

71. Wilson, S.; Zarate, O. (2002). The Freud Wars. Cambridge, Icon Books.

72. Wood, E. M. (2016). Od državljanov do gospode: socialna zgodovina zahodne politične misli od antike do srednjega veka. Ljubljana, Sophia.

73. Wright, R. (2008). Moralna žival. Pogledi evolucijske psihologije na človeško naravo. Ljubljana, Mladinska knjiga.

74. Zucman, G. (2016). Skrito bogastvo narodov: raziskava o davčnih oazah. Ljubljana, Sophia.

75. Žižek, S. (2005). Kako biti nihče. Ljubljana, Društvo za teoretsko psihoanalizo.

\section{Zoran Kanduč*}

Sažetak

\section{DUŠA, NJEZINI PUTEVI I STRANPUTICE, DRUŠTVENI NADZOR I KAPITALIZAM}

Tekst uvodno osvjetljava odnose između tijela i „duše“, zapravo duševnih pojava, jer tog metafizičkog entiteta nema ni u objektivnom ni u subjektivnom svijetu - za razliku od konkretnog, nehotično mijenjajućeg toka svjesnih iskustava (koja su za pojedinca nešto najrealnije, iako se još uvijek ne zna kako nastaju i čemu služe), a nije ju moguće utemeljiti ili pojasniti niti pomoću evolucijske teorije. Duša (u svojoj jedinstvenoj i besmrtnoj formi), koju je Bog podario samo ljudskoj „kruni stvaranja“, postoji samo u religijskoj perspektivi odnosno kao ,isključivo“ intersubjektivna, u kolektivnoj mašti i komunikaciji uspostavljena i održavana realnost, koja još uvijek ima nimalo zanemariv upliv na izniman broj ljudi, i to ne samo vjernika. Međutim, dogmatici bioloških znanosti i dalje sve više narušavaju vjeru u postojanje slobodne volje i jednog samostalnog, nedjeljivog i autentičnog (,stvarnoga“) ja (sebstva), koji je u optici liberalnog humanizma ultimativni izvor smisla, ekonomskih odluka te estetskih, moralnih i političkih sudova. U središnjem dijelu rada analizira se shvaćanje ljudske duhovnosti i njegova utjecaja na organizaciju društvenog nadzora, izvršavanje vlasti i opravdavanje hijerarhija, koje su izvorno u pravilu uvijek zamišljene, no s vremenom postaju sve više empirijski opipljive i okoštale. Ona kao zloslutna proročanstva, ostvaruju se sama - dok ih „oni i one ispod“ (prividno manje vrijedni i obično zapostavljeni, ugnjetavani, iskorištavani, prezirani ili čak omraženi subjekti) političkom borbom ne dovedu u pitanje, što se u povijesti događa vrlo rijetko, jako polagano i ne uvijek uspješno. $\mathrm{S}$ tim u vezi, posebna je pozornost posvećena

* Zoran Kanduč, Ph. D., Associate Professor, The Institute of Criminology at the Faculty of Law, University of Ljubljana; zoran.kanduc@pf.uni-lj.si 
razotkrivanju i proučavanju različitih značenja emocionalno snažno opterećene riječi „sloboda“. U zaključnom dijelu riječ je o duševnim smetnjama i normalnosti, i to ponajprije $u$ vezi s nasilnim ponašanjem i različitim načinima suočavanja pojedinaca s „, i previše ljudskim“ problemom raznovrsnog trpljenja kao (po svoj vjerojatnosti nepopravljive) tegobe, koja ga ne zahvaća zbog ovog ili onog peha, zle sudbine ili nesretne konstelacije zvijezda i planeta, nego samo zato jer je živ, što je kao subjekt uhvaćen $\mathrm{u}$ život $-\mathrm{u}$ neuspjeh vlastitog nerođenja - i s njim povezane prirodne mehanizme za koje se često priljepljuje još gomila društveno, kulturno i međusobno generirane nesreće. Najkraće i najkarikiranije: ljudska egzistencija = duševna smetnja. Ta se tegoba danas sve više „rješava“ kupovanjem komercijalnih dobara i usluga koje obećavaju doživljavanje ugodnih osjećaja (i eo ipso sreću) i uživanjem lijekova ili (zakonitih i nezakonitih) droga, koje neposredno mijenjaju biokemijski sustav pojedinca. To ima više nego opipljive kriminogene učinke jer je većina kriminalnog ponašanja posredno ili neposredno povezana s težnjom pojedinca $\mathrm{k}$ sreći (s čežnjom prema ugodnim osjećajima i netolerancijom neugodnih osjećaja).

Ključne riječi: duhovnost, tijelo, nadzor, vlast, hijerarhije, sloboda, samokontrola, duševne smetnje, nasilje.

Summary

\section{MIND, ITS STRAIGHT AND DEVIANT WAYS, SOCIAL CONTROL, AND CAPITALISM}

The article deals initially with the relationship between the body and the soul or rather mental phenomena, for the soul as a metaphysical entity does not exist in objective and subjective world (what does exist is the concrete, continually changing stream of subjective experiences being something that is the most real for every person, although modern science still cannot explain how our consciousness emerges from the brain and what are its biological functions). Moreover, the existence of eternal, individual, immortal soul cannot be explained with the Darwinian theory of evolution. The soul, as the exclusive gift given to the humans by the God, exists only in the religious perspective, i.e. as "solely" intersubjective, in the collective imagination and communication established and reproduced reality, still influencing thoughts and actions of considerable number of people (not only believers). Results of contemporary life sciences shake and tear up also the belief in free will and existence of one single, individual, authentic (or ,true“) self which is in the perspective of liberal humanism (as dominant ideology) the most important source of meaning, economic decisions, and moral, political and legal judgements. The central part of the article deals with various cultural „constructions“ of human mind and their influence on the organisation of social control, execution of power, and justifications of hierarchies (that are at first almost always imagined, but in the course of time they become more and more empirical and ossified: just as sinister self-fulfilling prophecies existing until 
they are not questioned by the political struggles of supposedly inferior, exploited, and oppressed human beings, that is by successful rebellions that are surprisingly quite rare historical events). In that regard, we pay special attention to various meanings of the emotionally much burdened word "freedom" (or „liberty“). The final part of the article focuses on troubled, disturbed, pathological and normal mental phenomena, particularly in connection with violent behaviour and coping with the ,all too human“ problem of divers forms of suffering, as (probably not abolishable) sorrow being not just the effect of some sort of bad luck, evil destiny or bad constellation of stars and planets, but of the bare fact that you are alive and as a subject captured in the live organism and its natural urges, needs and mechanisms. What is more, these inevitable sources of human suffering are accompanied by socially, culturally and interpersonally generated woe. Boldly put: human existence equals psychic troubles. Nowadays, people try to "solve“ this hard problem mainly by means of commercial (consumer) goods and services (that promise much desired experience of pleasant feelings and eo ipso happiness), and by medical and (legal and illegal) drugs that directly change biochemical system of individuals. Yet, that has considerable effects on crime. Namely, most criminal behaviour is directly or indirectly connected to the human aspiration after happiness, i.e. striving after pleasant feelings and intolerance to unpleasant ones.

Keywords: mind, body, control, power, hierarchies, freedom, self-control, mental troubles, violence.

Zussamenfassung

\section{DIE SEELE, IHRE WEGE UND IRRWEGE, SOZIALE KONTROLLE UND KAPITALISMUS}

Einführend erläutert die vorliegende Arbeit die Beziehungen zwischen dem Körper und der „Seele“, beziehungsweise den seelischen Erscheinungen, weil sich die Seele, im Unterschied zu konkretem ständigem Ablauf bewusster Erfahrungen (die für den Einzelnen etwas Normales darstellen, obwohl man dessen Zweck noch nicht festgestellt hat), weder begründen noch mit Hilfe der Evolutionstheorie erklären lässt. Die Seele (in ihrer einheitlichen und unsterblichen Form), welche als Krone der Gottesschöpfung nur den Menschen geschenkt wurde, existiert nur in der Religion, beziehungsweise ausschließlich in der ,intersubjektiven“ Form der kollektiven Phantasie und Kommunikation. Trotzdem übt die Seele einen wesentlichen Einfluss auf zahlreiche Menschen (auch Nichtgläubiger) aus. Naturwissenschaftler aber untergraben den Glauben an freien Willen und an ein einheitliches, unteilbares und authentisches Selbst (Wesen), welches im liberalen Humanismus die Quelle ultimativen Sinns, wirtschaftlicher Entscheidungen sowie auch ästhetischer, moralischer und politischer Ermessen darstellt. Im mittleren Teil der Arbeit wird die Auffassung der Geistigkeit und ihr Einfluss auf die Organisation sozialer Kontrolle, die Gewaltausübung und die 
Rechtfertigung der Hierarchien analysiert. Diese Hierarchien existieren am Anfang nur als Phantasien, aber mit Zeit werden sie immer mehr empirisch fassbar (und zwar als selbsterfüllende ominöse Prophezeiungen), bis sie von den Untergeordneten (scheinbar wenig wertvollen und gewöhnlich vernachlässigten, unterdrückten, ausgenutzten, verachteten oder auch verhaßten Einzelnen) durch politischen Kampf in Frage gestellt werden. In der Geschichte allerdings kam das nur selten vor und lief sehr langsam und nicht immer erfolgreich. Diesbezüglich legt man in der Arbeit besonderen Wert auf unterschiedliche Bedeutungen des emotional stark belasteten Wortes „Freiheit“. Abschließend werden in der Arbeit seelische Störungen und Normalzustände bearbeitet, vor allem bezüglich Gewaltverhaltens und unterschiedlicher Weisen der Auseinandersetzung des Einzelnen mit dieser Beschwerde, welche nicht nur wegen schlechten Schicksals, sondern blo $\beta$ wegen der Tatsache, dass man lebt, entsteht. Kurz gesagt ist menschliche Existenz gleich seelische Störung. Heutzutage setzt man sich mit diesem Problem durch das Kaufen komerzieller Güter und Dienstleistungen auseinander, was gute Gefühle (und eo ipso Glück) hervorruft. Andererseits wird diese Beschwerde durch den Konsum von Medikamenten und (legalen und illegalen) Drogen behandelt, was wiederum das biochemische System des Einzelnen verändert. Selbstverständlich hat das Auswirkungen auf das Strafrecht, weil kriminelles Verhalten mittelbar oder unmittelbar mit dem Streben des Einzelnen nach Glück (mit Sehnen nach angenehmen Gefühlen und Intoleranz unangenehmer Gefühle) verbunden ist.

Schlüsselwörter: Geistigkeit, Körper, Kontrolle, Gewalt, Hierarchien, Freiheit, Selbstkontrolle, seelische Störungen, Gewaltsamkeit.

\section{Riassunto}

\section{L'ANIMA, LE SUE VIE PRINCIPALI E TRAVERSE, IL CONTROLLO SOCIALE E IL CAPITALISMO}

Il testo introduce alla riflessione sui rapporti tra il corpo e l',,anima“, o meglio gli stati dell'anima, posto che tale entità metafisica non esiste nel mondo oggettivo, né in quello soggettivo - a differenza del concreto, involontario mutevole corso delle esperienze coscienti (le quali per il soggetto sono qualcosa di più realistico, sebbene non sappiamo come sorgano e a che cosa servano). Non è nemmeno possibile basare o spiegare gli stati dell'animo fondandosi sulla teoria evolutiva. L'anima (nella sua forma unica ed immortale) donata agli umani da Dio, esiste soltanto in una prospettiva religiosa. Essa è unicamente ,intersoggettiva“ nella fantasia collettiva nel dialogo con la realtà, benché abbia un'influenza affatto trascurabile su di un numero considerevole di persone - non solo credenti. Nondimeno, i dommatici delle scienze biologiche continuano ad incrinare la fede nell'esistenza di una volontà libera e di un indipendente, invisibile ed autentico ("reale") io, il quale in un'ottica di umanesimo liberale rappresenta la fonte ultima del senso, delle decisioni economiche e dei giudizi 
estetici, morali e politici. La parte centrale del testo si compone dell'analisi della comprensione della spiritualità umana e della sua influenza sull'organizzazione del controllo sociale, sull'espressione del potere e sulla giustificazione delle gerarchie. Quest'ultime, di regola, sono sempre immaginarie, ma che col passare del tempo stanno diventando sempre più tangibili empiricamente e concrete, quali oscuri oracoli, che si realizzano di per sé - fino a quando „essi ed esse che si trovano sotto ,(verosimilmente soggetti di valore inferiore e trascurati, usati, sfruttati o, addirittura, detestati) mediante la lotta politica non inizino a metterle in discussione. Ciò nella storia avviene molto raramente; molto lentamente e non sempre con successo. A tale riguardo, particolare attenzione viene dedicata alla scoperta ed allo studio dei differenti significati della parola - fortemente condizionata nell'aspetto emotivo - „libertà „. Nella parte conclusiva del lavoro si tratta dei disturbi mentali e della normalità e ciò principalmente con riguardo al comportamento violento ed ai diversi modi che i singoli hanno di confrontarsi con il problema "della troppo umana“ sopportazione, quale (probabilmente irreparabile) sofferenza, che non ti assale a causa di questa o quella sfortuna, della cattiva sorte o dell'avversa costellazione degli astri; ma soltanto perché sei vivo e perché come essere vivente - colto nell'insuccesso della non venuta al mondo - che seco porta i meccanismi naturali che solitamente vengono imputati a numerose sfortune sociali, culturali e interpersonali. Nel modo più breve e più eccessivo: l'esistenza umana = disturbo dell'anima. Tale sofferenza al giorno d'oggi si risolve sempre di più acquistando beni commerciali e servizi che promettono di vivere sensazioni piacevoli (e eo ipso la gioia) e consumando farmaci oppure stupefacenti (legali ed illegali), i quali direttamente mutano il sistema biochimico del soggetto. Ciò comporta effetti criminogeni più che tangibili, poiché la maggiore parte dei comportamenti criminali indirettamente o direttamente è collegata con la ricerca della felicità da parte del singolo (nella nostalgia delle sensazioni piacevoli e nella intolleranza delle sensazioni sgradevoli).

Parole chiave: spiritualità, corpo, controllo, potere, gerarchia, libertà, autocontrollo, disturbi mentali, violenza. 